OPEN ACCESS

Edited by:

Rohan Mahendra Shah,

Swinburne University of

Technology, Australia

Reviewed by:

N. K. Dubey,

Banaras Hindu University, India

Abhinav Upadhyay,

University of Connecticut,

United States

Chiara Dall'Asta,

University of Parma, Italy

${ }^{*}$ Correspondence:

Abhishek Kumar Dwivedy abhishekdwivedy1987@gmail.com

Specialty section:

This article was submitted to

Agro-Food Safety,

a section of the journal

Frontiers in Sustainable Food Systems

Received: 14 January 2021 Accepted: 01 April 2021

Published: 20 May 2021

Citation:

Maurya A, Prasad J, Das S and Dwivedy AK (2021) Essential Oils and

Their Application in Food Safety.

Front. Sustain. Food Syst. 5:653420.

doi: 10.3389/fsufs.2021.653420

\section{Essential Oils and Their Application in Food Safety}

\author{
Akash Maurya, Jitendra Prasad, Somenath Das and Abhishek Kumar Dwivedy* \\ Laboratory of Herbal Pesticides, Department of Botany, Institute of Science, Banaras Hindu University, Varanasi, India
}

Food industries are facing a great challenge due to contamination of food products with different microbes such as bacteria, fungi, viruses, parasites, etc. These microbes deteriorate food items by producing different toxins during pre- and postharvest processing. Mycotoxins are one of the most potent and well-studied toxic food contaminants of fungal origin, causing a severe health hazard to humans. The application of synthetic chemicals as food preservatives poses a real scourge in the present scenario due to their bio-incompatibility, non-biodegradability, and environmental non-sustainability. Therefore, plant-based antimicrobials, including essential oils, have developed cumulative interest as a potential alternative to synthetic preservatives because of their ecofriendly nature and generally recognized as safe status. However, the practical utilization of essential oils as an efficient antimicrobial in the food industry is challenging due to their volatile nature, less solubility, and high instability. The recent application of different delivery strategies viz. nanoencapsulation, active packaging, and polymer-based coating effectively addressed these challenges and improved the bioefficacy and controlled release of essential oils. This article provides an overview of essential oils for the preservation of stored foods against bacteria, fungi, and mycotoxins, along with the specialized mechanism of action and technological advancement by using different delivery systems for their effective application in food and agricultural industries smart green preservative.

Keywords: essential oils, antimicrobial, mycotoxin, nanoencapsulation, food safety

\section{INTRODUCTION}

Currently, the achievement of food security is based on food access, food stability, food utilization, and, most importantly, its preservation to avoid further contamination. These four food pillars constitute the socioeconomic background and influence the affordable food requirement. With regards to food insecurity, the microbes and their associated toxins are prime driving factors for major food spoilage and biodeterioration due to their long-term impact along the food chain and food web. In several developing countries, $25-30 \%$ loss of foods has been reported due to microbial contamination (Bondi et al., 2017). Microbial contamination of foods in different stages of production and processing causes different foodborne diseases. In addition to microbial contamination, some bacteria and fungi are reported to produce toxins. Many of these microbial toxins are thermostable in nature and are not destroyed by high temperatures during cooking or food processing (Rajkovic, 2014). Bacteria produced two different types of toxins viz. endotoxins and exotoxins. Exotoxins are proteinaceous substances secreted by Clostridium botulinum, Staphylococcus aureus, Bacillus cereus, and Clostridium perfringens 
(Josić et al., 2017; Rajkovic et al., 2020), whereas endotoxins are lipopolysaccharide (LPS) components and more powerful as well as specific to their target site (Rešetar et al., 2015). In addition to food pathogenic bacteria, different fungal species also play an active role in food deterioration by sporulation and production of mycotoxins. Mycotoxins are defined as low molecular weight secondary metabolites mostly synthesized by different fungal genera such as Penicillium, Aspergillus, and Fusarium, contaminating several stored food items with variable toxic effects, viz. carcinogenicity, teratogenicity, neurotoxicity, and hepatotoxicity. Till now, more than 400 different food-contaminating mycotoxins have been identified and characterized. Among them, aflatoxins, fumonisins, ochratoxins, zearalenone, and trichothecenes exhibit widespread occurrence on the basis of substrate type, relative humidity, moisture content, and water activity of the substrate causing maximum health-related problems and a key factor for prime destruction of the worldwide agricultural economy (Reddy et al., 2010). Moreover, the International Agency for Research on Cancer (2012) has classified aflatoxin $B_{1}$, aflatoxin $B_{2}$, aflatoxin $G_{1}$, aflatoxin $G_{2}$, and aflatoxin $M_{1}$ as class 1 human carcinogen (mycotoxins that are completely carcinogenic to humans). Ochratoxin $A$, fumonisin $B_{1}$, fumonisin $B_{2}$, sterigmatocystin, and fusarin $\mathrm{C}$ have been categorized as class $2 \mathrm{~B}$ human carcinogen (mycotoxins that are possibly carcinogenic to humans), whereas deoxynivalenol, zearalenone, patulin, and citrinin have been grouped under class 3 human carcinogen (mycotoxins are not classifiable based on their carcinogenicity).

Different chemical preservatives such as sulfur dioxide, sulfites, sodium nitrite, sodium benzoate, benzoates, sorbates, formaldehyde, imidazoles, pyrrolidines, and thiocyanates have achieved significant contribution in controlling the microbial contamination of foods items (Gutiérrez-del-Río et al., 2018). However, these chemical preservatives have raised negative concerns to the consumer based on their long-term degradation cycles, environmental toxicology, pest resurgence, and potential risks of carcinogenesis and teratogenesis to humans and animals (Basak and Guha, 2018; Falleh et al., 2020). Therefore, plantbased preservatives, especially EOs and their active components extracted from aromatic and medicinally important plants, are gaining cumulative attention in the food industries having wide-spectrum antibacterial, antifungal, antimycotoxicgenic, and antioxidants properties. Furthermore, the application of EOs extends a novel eco-friendly approach toward food protection due to their inclusion under generally recognized as safe category and exemption from mammalian toxicity by the United States Food and Drug Administration (Pisoschi et al., 2018; Bhavaniramya et al., 2019; Chaudhari et al., 2020a).

EOs are composed of a complex mixture of terpenes, terpenoids, phenylpropanoids, and various compounds of low molecular weight (Nikmaram et al., 2018; Wińska et al., 2019). Several workers have reported wide-scale antimicrobial property of EOs in the different postharvest stored food system (Brahmi et al., 2016; Dwivedy et al., 2017; Ouedrhiri et al., 2017; Das et al., 2019a; Perczak et al., 2019; Restuccia et al., 2019; Kumar A. et al., 2020; Nikkhah and Hashemi, 2020). Due to their hydrophobic/lipophilic nature, EOs are effectively passed through the lipid bilayer of cell membranes, thus interfering with the ion transport, leakage of cellular materials, alternation in proton motive force-mediated electron flow, and eventually lead to apoptosis (Debonne et al., 2018; Pisoschi et al., 2018; Reyes-Jurado et al., 2020). EOs have prominent effects on gram positive-bacteria compared with gram-negative bacteria due to the presence of the outer LPS layer restricting the flow rate of lipophilic EOs into the intracellular environment (Tehrani and Sadeghi, 2015; Dhifi et al., 2016).

Despite the significant preservative efficacy of EOs in the food system, some limitation has been recognized in their practical application due to intense aroma, high reactivity, hydrophobicity, reduced solubility, and possible negative interaction with carbohydrate, fat, and fatty acids of food leading to changes in organoleptic properties. Several modern technological advancements involving different delivery systems have been used to rectify these shortcomings. Nanoencapsulation of EOs is one of the novel and innovative delivery strategies, which enhance antimicrobial efficacy via improvement in stability, solubility, and controlled release of EO aroma in the food system and protect from environmental interactions (light, oxygen, moisture, and pH) (Pisoschi et al., 2018; Amiri et al., 2020; Delshadi et al., 2020). Several biopolymeric matrices viz. chitosan, dextran, starch, cellulose, and alginate have been used as a carrier agent for the encapsulation of EO owing to their biodegradable, biocompatible, and non-toxic nature (Hosseini and Meimandipour, 2018). Therefore, encapsulated EOs could be the best non-toxic and eco-friendly alternatives of synthetic preservatives for practical application in the field of agriculture and the food sector. Active food packaging and polymer-based coating using EOs have been recognized as another promising delivery approach that creates a barrier that protects food from microbial infestation and toxin production facilitating enhancement in food shelf life. In this context, this review aimed to present updated information about the application of EOs in foods as eco-friendly preservatives with emphasis on the antimicrobial mechanism of action and different modern delivery approaches for controlled volatilization of EOs with consistent long-term efficacy in the food system as a smart green preservative.

\section{ESSENTIAL OILS AND THEIR CHEMICAL COMPOSITIONS}

EOs are major secondary metabolic products isolated from leaves, bark, flowers, bud, seed, root, stem, and fruits of different aromatic plants. The name "essential oil" has been originated from "essence," i.e., presence of fragrance as well as flavors. A multitude of structurally related low molecular weight lipophilic short-chain aliphatic hydrocarbons, phenyl propanoids, terpenoids, and phenolic constituents has been observed in EOs. In addition, hydrocarbons and oxygenated compounds such as aldehydes, ketones, esters, oxides, and alcohols are also actively participated in the production of EOs in different aromatic plants (Baldim et al., 2019). Hydrodistillaton, a common extracting method, is utilized to isolate oils from 
plant parts (Silvestre et al., 2019). The bioactive components of EOs are volatile in nature, provide a well-built odor, and have abilities to give up aroma or flavor (Smith et al., 2005). EOs are isolated from different plant species, including the families Asteraceae, Lamiaceae, Cyperaceae, Zingerberaceae, Piperaceae, Apiaceae, Myrtaceae, Solanaceae, Apocynaceae, and Lauraceae (Nuzhat and Vidyasagar, 2014). EOs exhibit some beneficial role for plant defense in the environment, for example, (1) tolerating the environmental stress, (2) excellent antifungal and antimicrobial activities, and (3) potential importance in food and pharma industries (Burt, 2004; Dhifi et al., 2016). Eugenol was reported as a major bioactive constituent of Cinnamomum verum EO having significant anticancer as well as antimicrobial activity. Thymus persicus, an important medicinal plant belonging to the family Lamiaceae, is actively used as an antifungal, antitumor, antibacterial, and antiviral agent. The EO of T. persicus is composed of different volatile components such as carvacrol (27.01\%), thymol (11.86\%), p-cymene (10.16\%), and $\alpha$-terpineol (Rasooli and Mirmostafa, 2003). Thymol (27\%) and carvacrol (30\%) have been found as major components of Origanum compactum EO (Bouhdid et al., 2008). Camphor and $\alpha$ - and $\beta$-thuoyne were observed as a major ingredient of Artemisia herba-alba EO (Dahmani-Hamzaoui and Baaliouamer, 2010), carvone (58\%), and limonene (37\%) of the Anethum graveolens EO (Jirovetz et al., 2003) and linalool (68\%) as the Coriandrum sativum EO (Matasyoh et al., 2009). The biosynthesis of the EO components is based on two major pathways, viz. terpenoid and aromatic constituent pathways. The secondary metabolism pathway is affected by different environmental factors during the growing season at various developmental stages (Sampaio et al., 2016). Terpenes are mainly synthesized from isopentenyl diphosphate precursor followed by modification in prenyl diphosphate by terpene synthetase enzymes. The distribution of EO components is determined by gas chromatographymass spectrometry technology. Major hemiterpenes (C5), sesquiterpenes (C15), monoterpenes (C10), triterpenes (30), diterpenes (C20), and tetraterpenes (C40), alcohol, aldehyde, ketone, ester, ether, and phenols of different EOs are myrcene, phellandrene, sabinene, camphene, pinene, 3-carene, borneol, $\alpha$-terpeniol, geranial, citronellal, fenchone, camphor, linalyl acetate, 1,8-cineol, carvacrol, and thymol, respectively. Among different bioactive ingredients, monoterpenes are reported as the most abundant components, mostly $90 \%$ in occurrence availability (Bakkali et al., 2008; Caputo et al., 2018). Aromatic components of EOs are the derivative of phenylpropane and less frequently observed than terpenes. The pathway for synthesis of phenylpropanic and terpenes derivatives are separated in plants, but sometimes they have coexisted in the shikimic acid pathway. Common aromatic aldehyde, alcohols, phenols, and methoxy derivatives of EOs are cinnamaldehyde, cinnamic alcohol, eugenol, elemicin, estragol, and anethole (Wang et al., 2009). EOs containing the principal aromatic components are observed in Myristica fragrans, Petroselinum crispum, Illicium verum, A. graveolens, Eugenia caryophyllata, Pimpinella anisum, and Foeniculum vulgare (Narasimhan and Dhake, 2006; Callan et al., 2007; Rather et al., 2016). Sulfur or nitrogenous components such as glucosinolates and isothiocyanates are common in members of Brassicaceae with diversified secondary metabolic origins. Some common EOs with their major components and percent occurrence are presented in Table 1.

\section{ANTIMICROBIAL AND ANTIMYCOTOXIGENIC ACTIVITY OF ESSENTIAL OILS IN FOOD}

Several synthetic preservatives are being widely used to inhibit the severity of the microbial infestation and toxin production in food commodities during postharvest storage; however, the negative effect on health, possibility to develop resistant microbial strains, and harmful effects on environmental sustainability by some adverse chemical reactions are commonly ignored by the modern consumers. Therefore, foodborne diseases especially caused by bacteria, fungi, and their associated toxins are a burning issue for food industries today. Moreover, safety and toxicity issues limit the excessive application of chemical preservatives. The ingestion of the synthetic preservative components associated with food items for prolonged periods may develop toxic potential to the heart and nervous system. EOs exhibit broad-spectrum antimicrobial, fungitoxic, and antimycotoxigenic properties in postharvest stored food items (Hyldgaard et al., 2012; Tongnuanchan and Benjakul, 2014). The idea for the application of EO in the management of stored food came from its variable bioefficacy viz. antiviral, antidepressant, antibacterial, and toxin (bacterial toxins and mycotoxins) detoxification activities (Mancini et al., 2014; Elshafie and Camele, 2016), ensuring its utilization as a green alternative of synthetic preservatives. A wide range of literature is available on the application of EOs as a natural antimicrobial, antifungal, and antimyctoxigenic agent in the model and food system. Dwivedy et al. (2017) studied the potentiality of Mentha cardiaca EO as a green alternative to protect fungal and $\mathrm{AFB}_{1}$ contamination in stored dry fruits. The in vitro antifungal and antiaflatoxigenic activities of $M$. cardiaca EO were recorded as 1.25 and $1.0 \mu \mathrm{l} / \mathrm{ml}$, respectively. In addition to broad range food-contaminating fungi and $\mathrm{AFB}_{1}$ inhibition, the EO also displayed potent antioxidant activity $\left(\mathrm{DPPH}_{\mathrm{IC50}}=15.89 \mu \mathrm{l} / \mathrm{ml}\right)$ that helped in the protection of dry fruits from lipid peroxidation by scavenging biodeteriorating free radicals. Moreover, the $\mathrm{EO}$ showed a favorable $\mathrm{LD}_{50}$ value $(7,133.70 \mathrm{mg} / \mathrm{kg})$, representing the mammalian non-toxicity and suggested large-scale practical application as shelf life enhancer of food commodities. Kumar M. et al. (2020) investigated the in vitro and in vivo efficacy of Artemisia nilagirica EO for shelf life enhancement of stored millets by preventing fungal infestation and $\mathrm{AFB}_{1}$ contamination. During in vitro testing, the growth of toxigenic Aspergillus flavus and $\mathrm{AFB}_{1}$ secretion was completely inhibited at 1.4 and $1.0 \mu \mathrm{l} / \mathrm{ml}$, respectively. The EO exhibited strong antioxidant activity $\left(\mathrm{DPPH}_{\mathrm{IC} 50}=2.51\right.$ and $\mathrm{ABTS}_{\text {IC50 }}=1.07 \mu \mathrm{l} / \mathrm{ml}$ ), which significantly inhibited the $\mathrm{AFB}_{1}$ biosynthesis by scavenging the free radicals and prevented the risk of nutritional quality deterioration by oxidation of food components. Moreover, in vivo efficacy of EO was tested in 
TABLE 1 | List of some common essential oils, their source with major components, and percent occurrence.

\begin{tabular}{|c|c|c|c|}
\hline Plant name & Plant part used & Category of principle components & References \\
\hline Boswellia ovalifoliolata & Leaves & $\begin{array}{l}\text { Sesquiterpene: } \\
\text { Spathulenol (11.1\%), caryophyllene oxide (9.0\%), } \\
\text { decyl acetate (6.3\%), and calacorene (3.3\%) } \\
\text { Monoterpene alcohol: } \\
\text { Myrtenol (3.2\%) and nerolidol (3.1\%). } \\
\text { Sesquiterpene: } \\
\beta \text {-Farnesene (13.4\%), caryophyllene oxide (10.5\%), spathulenol } \\
(6.6 \%) \text {, and nerolidol (2.4\%) }\end{array}$ & $\begin{array}{l}\text { Geetha and Chakravarthula, } \\
2018\end{array}$ \\
\hline Oliveria decumbens & Flower buds & $\begin{array}{l}\text { Monoterpene: } \\
\text { Thymol (37.8\%), } \gamma \text {-terpene (10.3\%), and p-cymene (10.07\%) } \\
\text { Phenol: } \\
\text { Carvacrol (29.3\%) }\end{array}$ & Esmaeili et al., 2018 \\
\hline Salvia officinalis & $\begin{array}{l}\text { Leaves } \\
\text { Flowers }\end{array}$ & $\begin{array}{l}\text { Monoterpene: } \\
\beta \text {-thujone (14.86\%), eucalyptol (14.82\%), camphor (12.7\%), and } \\
\text { borneol (10.17\%) } \\
\text { Sesquiterpene: } \\
\text { Ledol (5.94\%) and caryophyllene (3.38\%) } \\
\text { Monoterpene: } \\
\alpha \text {-thujone (19.63\%), } \beta \text {-pinene (15.15\%), eucalyptol, and borneol } \\
(6.71 \%) \\
\text { Sesquiterpene: } \\
\text { Ledol (7.92) and caryophyllene (4.64\%) }\end{array}$ & Li et al., 2015 \\
\hline Pelargonium graveolens & Leaves and stem & $\begin{array}{l}\text { Monoterpene: } \\
\text { Citronellol (25.24\%), geraniol (23.36\%), linalool (7.11\%), and } \\
\text { iso-menthone (3.37\%) } \\
\text { Sesquiterpene: } \\
\beta \text {-eudesmol }(6.13 \%)\end{array}$ & Moutaouafiq et al., 2019 \\
\hline Lavandula rejdalii & Leaves & $\begin{array}{l}\text { Oxygenated monoterpenes: } \\
\text { Linalool (32.03\%), camphor (11.03\%), 1, 8- cineole (9.67\%), and } \\
\text { lilanyl acetate (9.02\%) } \\
\text { Phenol: } \\
\text { Carvacrol (19.6\%) }\end{array}$ & Gharby et al., 2020 \\
\hline Mentha arvensis & Leaves & $\begin{array}{l}\text { Monoterpenoids: } \\
\text { Menthol }(86.1 \%) \text {, menthone }(4.3 \%) \text {, iso-menthone }(3.7 \%) \text {, and } \\
\text { pulegone }(1.3 \%) \\
\text { Aliphatic hydrocarbon: } \\
\text { Limonene }(1.0 \%)\end{array}$ & Chagas et al., 2020 \\
\hline Origanum vulgare & Leaves and stem & $\begin{array}{l}\text { Monoterpene: } \\
\text { Thymol (45.43\%) and } \gamma \text {-terpene (23.69\%) }\end{array}$ & Vinciguerra et al., 2019 \\
\hline Citrus limon var. pompia & Leaves & $\begin{array}{l}\text { Aliphatic: } \\
\text { Limonene (29.8\%) } \\
\text { Monoterpene: } \\
\text { Myrcene (9.7\%), linalool (9.1\%), and geraniol (8.9\%) } \\
\text { Sesquiterpene: } \\
\beta \text {-Caryophyllene (9.6\%) }\end{array}$ & Fancello et al., 2016 \\
\hline Perilla frutescens & Leaves and stem & $\begin{array}{l}\text { Monoterpene: } \\
\text { Linalool (46.55\%) and 2-hexanoylfuran (30.79\%) } \\
\text { Sesquiterpene hydrocarbon: } \\
\beta \text {-Caryophyllene }(5.34 \%)\end{array}$ & Luo et al., 2019 \\
\hline Plectranthus asirensis & Leaves and stem & $\begin{array}{l}\text { Monoterpene: } \\
\alpha \text {-Pinene (8.6\%) and borneol (2.1\%) } \\
\text { Sesquiterpene: } \\
\beta \text {-Caryophyllene }(13.3 \%) \text {, spathulenol (8.7\%), and } \\
\text { bicyclogermacrene }(7.4 \%)\end{array}$ & Mothana et al., 2018 \\
\hline
\end{tabular}


TABLE 1 | Continued

\begin{tabular}{|c|c|c|c|}
\hline Plant name & Plant part used & Category of principle components & References \\
\hline Heracleum lehmannianum & $\begin{array}{l}\text { Leaves, flower and } \\
\text { stem }\end{array}$ & $\begin{array}{l}\text { Monoterpene hydrocarbons: } \\
\alpha \text {-phellandrene (10.5\%) and 4-terpineol (2.4\%) } \\
\text { Aliphatic alcohol: } \\
\text { 1-butanol ( } 9.0 \%) \\
\text { Sesquiterpene hydrocarbons: } \\
\delta \text {-cadinene }(6.2 \%), \alpha \text {-cadinol (5.7\%), and } \tau \text {-muurolol }\end{array}$ & Mamadalieva et al., 2018 \\
\hline Bunium persicum & Dried seed & $\begin{array}{l}\text { Monoterpene: } \\
\gamma \text {-Terpinene }(25.77 \%) \text { and } \alpha \text {-terpinen-7-al (12.78\%) } \\
\text { Benzaldehyde: } \\
\text { Cuminaldehyde (20.82\%) }\end{array}$ & Singh et al., 2020a \\
\hline Callistemon viminalis & Leaves and stem & $\begin{array}{l}\text { Monoterpene: } \\
\text { 1, 8-cineole (58.12\%), } \alpha \text {-terineol }(9.56 \%) \text {, geranial }(6.02 \%) \text {, } \\
\text { myrcene }(2.96 \%) \text {, and } \alpha \text {-pinene }(2.49 \%) \\
\text { Aliphatic hydrocarbon: } \\
\text { Limonene }(9.72 \%) \\
\text { Sesquiterpene hydrocarbons: } \\
\delta \text {-elemene }(3.53 \%)\end{array}$ & Fall et al., 2017 \\
\hline Melaleuca leucadendron & Leaves and stem & $\begin{array}{l}\text { Monoterpene hydrocarbons: } \\
\text { 1, 8-cineole, } \alpha \text {-pinene (12.22\%), and } \alpha \text {-terineol (7.06\%) } \\
\text { Sesquiterpene hydrocarbons: } \\
\text { Epiglobulol (23.06\%) } \\
\text { Aliphatic hydrocarbon: } \\
\text { Limonene }(11.65 \%)\end{array}$ & \\
\hline
\end{tabular}

stored Ragi (Elusine coracana) samples, and percent protection of fungal contamination was observed as 70.78 and $71.79 \%$ for inoculated and uninoculated samples, respectively. In a different study, Oliveira et al. (2020a) used Thymus vulgaris EO for in vitro inhibition of $A$. flavus and $\mathrm{AFB}_{1}$ secretion. The $\mathrm{EO}$ at 0.1 and $0.25 \mu \mathrm{l} / \mathrm{ml}$ significantly inhibited the growth with 1.3 and $0.5 \mathrm{~mm}$ day $^{-1}$, respectively. Moreover, the EO downregulated (49.4\%) the expression of laeA gene responsible for the production of aflatoxin synthesis. $M$. fragrans EO effectively reduced fungal proliferation on stored rice when applied at a concentration of $2.75 \mathrm{mg} / \mathrm{ml}$. The $\mathrm{AFB}_{1}$ biosynthesis was inhibited at $1.75 \mathrm{mg} / \mathrm{ml}$. The EO inhibited the production of cellular methylglyoxal up to $846 \mu \mathrm{M} / \mathrm{gFW}$, which helped in the mitigation of free radical-mediated oxidation of food components and $\mathrm{AFB}_{1}$ biosynthesis in food products. The antioxidant activities of EO were found to be at 3.74 and $0.24 \mathrm{mg} / \mathrm{ml}$ for DPPH and ABTS assay, respectively. In addition to fungal and $\mathrm{AFB}_{1}$ inhibition, the EO also exhibited a non-phytotoxic effect on the germination of rice seeds, suggesting future application for further intended agricultural practices (Das et al., 2020a,c). Singh et al. (2020a) investigated the in vitro efficacy of Cinnamomum cassia EO against broad-spectrum food-contaminating molds, viz. A. fumigatus, Aspergillus niger, A. flavus, A. versicolor, A. penicillioides, A. chevalieri, and Cladosporium herbarum, and $\mathrm{AFB}_{1}$ secretion in Phyllanthus emblica fruits. The in vitro antifungal and antiaflatoxigenic activity of EO was found as 0.06 $\mu \mathrm{l} / \mathrm{ml}$. The EO showed promising phenolic content $(7.52 \mu \mathrm{g}$ gallic acid equivalent) and significant free radical scavenging activity to protect the stored fruits from mold infestation and $\mathrm{AFB}_{1}$ contamination. Li et al. (2020) conducted a study to determine the efficacy of I. verum EO against toxigenic A. flavus and $\mathrm{AFB}_{1}$ and $\mathrm{AFB}_{2}$ biosynthesis to preserve lotus seeds. The EO completely inhibited fungal growth in in vitro conditions at $2.0 \mu \mathrm{l} / \mathrm{ml}$, whereas the minimum concentration representing the fungicidal action was recorded as $4.0 \mu \mathrm{l} / \mathrm{ml}$. During in vitro study, $\mathrm{AFB}_{1}$ and $\mathrm{AFB}_{2}$ biosynthesis was inhibited at 3.6 $\mu \mathrm{l} / \mathrm{ml}$ of $I$. verum $\mathrm{EO}$. The EO totally inhibited $\mathrm{AFB}_{1}$ and $\mathrm{AFB}_{2}$ biosynthesis in the in vivo condition (lotus seeds) at $6.0 \mu \mathrm{l} / \mathrm{g}$, somewhat higher than the in vitro dose. Chaudhari et al. (2020a) evaluated the efficacy of Origanum majorana EO as a novel preservative to mitigate the fungal and $\mathrm{AFB}_{1}$ contamination in stored maize with special emphasis to maintain its sensory attributes. The in vitro minimum inhibitory concentration and minimum aflatoxin inhibitory concentration of the $\mathrm{EO}$ were found as 2.5 and $1.5 \mu \mathrm{l} / \mathrm{ml}$, respectively. The EO displayed a broad range of fungitoxicity against several food-infesting fungi (Cladosporium cladosporoides, Penicillium italicum, P. chrysogenum, Fusarium poae, and Alternaria alternata), and the fungicidal nature of toxicity was determined. The EO effectively inhibited the biosynthesis of methylglyoxal, a prerequisite for $\mathrm{AFB}_{1}$ diminution in food commodities. Interestingly, the EO also showed prominent antioxidant activity, which can neutralize the free radicals more efficiently and inhibited the food biodeterioration process. During in situ efficacy in the food system, the control maize seeds (inoculated and uninoculated with toxigenic $A$. flavus spore suspension) were represented with 26.17 and $25.37 \mu \mathrm{g} / \mathrm{kg}$ of $\mathrm{AFB}_{1}$, whereas the EO treatment sets with no detectable $\mathrm{AFB}_{1}$ content was observed. The antioxidant activity of EO was also helpful in reducing the lipid peroxidation of maize seeds up to $192.2 \mu \mathrm{g}$ MDA/gFW during storage. Singh et al. (2020b) reported the efficacy of Bunium persicum EO against fungal infestation and $\mathrm{AFB}_{1}$ contamination in stored 
masticatories, viz. Glycyrhiza glabra (root), P. emblica (fruits), Terminalia chebula (fruits), Nicotiana tabacum (leaves), and Areca catechu (areca nut). The EO at $1.2 \mu \mathrm{l} / \mathrm{ml}$ completely inhibited the growth of toxigenic A. flavus and $\mathrm{AFB}_{1}$ secretion. Effective diminution in cellular methylglyoxal was also recorded, which suggested the antiaflatoxigenic mechanism of action of the EO. Moreover, the EO showed promising antioxidant capacity and phenolic content, facilitating a reduction in lipid peroxidation. In the case of in situ fumigation study in P. emblica fruits, mean $\mathrm{AFB}_{1}$ content in uninoculated and inoculated control was found as 40.19 and $46.33 \mu \mathrm{g} / \mathrm{kg}$, respectively, whereas $\mathrm{AFB}_{1}$ was totally absent in $\mathrm{EO}$ fumigated sets. The authors also revealed that at MIC and 2 MIC doses, sensory attributes of the $P$. emblica fruits were not altered, suggesting the practical utilization of EO as a shelf life enhancer. The in vitro and in vivo antifungal and antiaflatoxigenic activities of Curcuma longa $\mathrm{EO}$ in maize were investigated by $\mathrm{Hu}$ et al. (2017). After treatment with EO, the growth of A. flavus was significantly reduced, and at $8.0 \mu \mathrm{l} / \mathrm{ml}$, the percent inhibition of fungal growth was recorded as $94.31 \%$. At this concentration of EO, spore germination was inhibited by $85.17 \%$. During in vitro testing, $78.4 \%$ inhibition of $\mathrm{AFB}_{1}$ was observed at 8.0 $\mu \mathrm{l} / \mathrm{ml}$. In vivo results suggested the progressive tendency of fungal contamination and $\mathrm{AFB}_{1}$ production in stored maize in a time-dependent manner. After 5 days, $74.3 \%$ of maize seeds were contaminated by fungi, and $116.3 \mu \mathrm{g} / \mathrm{kg} \mathrm{AFB}_{1}$ was produced. Fumigation of maize seeds by EO $(4.0 \mu \mathrm{l} / \mathrm{ml})$ could reduce the fungal contamination, and $\mathrm{AFB}_{1}$ content $(7.76 \mu \mathrm{g} / \mathrm{kg})$ was also diminished. Effective antifungal and anti-aflatoxigenic properties of C. sativum and Carum carvi EOs in stored foods have been associated with the presence of several terpenoids and phenolic components (Lasram et al., 2019). In vitro minimal inhibitory concentrations of $C$. sativum and C. carvi EOs were found 0.7 and $0.4 \%$, respectively. Carvone and linalool showed a dose-dependent response to inhibit the A. flavus growth with resultant diminution of $\mathrm{AFB}_{1}$ production. $\mathrm{AFB}_{1}$ production of A. flavus in the control set was found nearly $10.70 \pm 0.55 \mu \mathrm{g} / \mathrm{g}$, whereas, at $0.1 \%$ of C. carvi and C. sativum EO, 49.4 and $45.6 \%$ inhibition of $\mathrm{AFB}_{1}$ production was achieved. They suggested the potential usefulness of the EOs for inhibition of postharvest fungal infestation and aflatoxin contamination in different food commodities. EOs obtained from leaves of Schinus lentiscifolius displayed strong antibacterial activity against common food contaminating bacteria, viz. Streptococcus pyogenes and S. aureus; however, the negligible antimicrobial property was reported from the fruits (Gehrke et al., 2013). In addition, Salmea scandens EOs extracted from the stem bark promptly showed antibacterial activity, whereas EO isolated from the leaves had not any significant antibacterial activity (Villa-Ruano et al., 2015). Cunha et al. (2020) reported the antifungal activity of Cymbopogon nardus EO against food-contaminating Candida albicans and $S$. aureus due to the presence of the most abundant bioactive compounds such as nerol (21.89\%), citronellal (27.53\%), and citronellol (25\%). Antibacterial activity of Litsea cubeba EO against food-contaminating methicillin-resistant $S$. aureus has been reported by $\mathrm{Hu}$ et al. (2019). Research findings illustrated the destructive effect of the EO on plasma membrane leading to leakage of cellular contents (DNA, RNA, and small proteins) and eventually the death of a cell. Minimum inhibitory concentration and minimum bactericidal concentration of the EO against methicillin-resistant $S$. aureus were found to be 0.5 and 1.0 $\mathrm{mg} / \mathrm{ml}$, respectively. Sodium dodecyl sulfate polyacrylamide gel electrophoresis analysis suggested the protein content in $S$. aureus was dropped down by $36.44 \%$ after treatment with the EO at MIC dose. Cellular adenosine triphosphate (ATP) content was reduced from $50 \pm 1.35$ to $34 \pm 1.23$ and $50 \pm 1.04$ to 19 $\pm 0.98 \mu \mathrm{mol} \mathrm{g} /$ protein at 0.25 and $0.50 \mathrm{mg} / \mathrm{ml}$ of EO treatment. In addition, the EO could inhibit the respiratory metabolism and lower the activity of glucose 6 phosphate dehydrogenase in the hexose monophosphate pathway. Semeniuc et al. (2017) demonstrated the in vitro antibacterial activity of T. vulgaris, Petroselinum crisnum, Ocimum bazilicum, and Levisticum officinale EO against four potential food-contaminating bacterial pathogens, viz. Salmonella typhimurium, S. aureus, Bacillus cereus, and Escherichia coli. Moreover, a combination of $P$. crisnum, O. bazilicum, and L. officinale, T. vulgaris EO displayed antagonistic effects against all the tested bacteria. Investigation on antibacterial activity of Cyperus rotundus EO against common food spoilage bacteria $S$. aureus has been illustrated by Zhang et al. (2017). The EO displayed strong in vitro antibacterial activity, with minimum inhibitory concentration and minimum bactericidal concentration at 10 and $20 \mathrm{mg} / \mathrm{ml}$, respectively. Increasing electrical conductivity was observed after treatment of bacterial culture with the EO, and subsequent losses of different electrolytes were also recorded. Antifungal activity of five different EOs such as Syzygium aromaticum, C. nardus, Cinnamomum camphora, Cinnamomum zeylanicum, Zanthoxylum bungeanum, and Mentha haplocalyx against $A$. niger, A. ocharceus, and A. oryzae isolated from wheat bread has been reported by $\mathrm{Hu}$ et al. (2019). Among all tested EOs, C. zeylanicum $\mathrm{EO}$ showed maximum antifungal activity against all the fungal species having the largest inhibition zone at $800 \mathrm{mg} / \mathrm{ml}$. In vitro minimum inhibitory concentrations of $S$. aromaticum and C. zeylanicum EO were 0.25 and $0.0625-0.125$ $\mathrm{mg} / \mathrm{ml}$, respectively. The sensitivity of three different fungi by EOs was in the order of $A$. ocharceus $>A$. oryzae $>A$. niger. In vivo investigation showed effective reduction of fungal spoilage (40-52\%) on wheat bread after fumigation with different EOs during 10 days of storage periods. Fungitoxic activity of Michelia alba EO and synergistic actions of caryophyllene and linalool against $A$. flavus infestation in brown rice have been demonstrated by Songsamoe et al. (2017). Results showed that, at a concentration of $M$. alba EO > $300 \mu \mathrm{l} / \mathrm{l}$, spore germination of $A$. flavus in brown rice was totally inhibited and extended the shelf life for 16 weeks. The caryophyllene and linalool combination $(10: 1)$ at $300 \mu \mathrm{l} / \mathrm{L}$ checked the mycelia proliferation in brown rice. Furthermore, the treatment of $M$. alba vapor to brown rice improved the qualities by reducing the hardness. Sensory analysis of texture, flavor, and color of EO-fumigated brown rice overall liking attributes up to 16 
weeks and strengthened the application of EO in intended agricultural practices.

\section{MECHANISMS OF ACTION OF ESSENTIAL OILS}

Although EOs are widely utilized in food safety, fragmentary reports are available about the antimicrobial mechanism of action of EOs with mechanistic details. Several EOs have been studied with excellent antimicrobial activity; however, the potential inhibitory mechanisms regarding microbial growth and reproduction were altered due to a complex mixture of terpenoids, phenolic acids, flavonoids, and phenylpropanoids in EO (Chaudhari et al., 2021). Moreover, the mechanism of toxicity in a microbial cell is strengthened by the types and chemical components of EOs. For example, the presence of phenolic content in EOs displayed more specificity for the inhibition of microbial growth based on their effective hydroxyl group in chemical structures, which help in disruption of plasma membrane structure and thus disorganize the membrane permeability, for example, the activity of the enzyme in Kreb's cycle. However, the terpenoids in EOs critically affect the plasma membrane fatty acids leading to alteration in membrane dynamicity, permeability, and leakage of cytoplasmic constituents (Bouyahya et al., 2019). Conversely, similar chemical constituents of EOs may display different effects when applied to another microorganism depending on the variability of membrane thickness, composition, and cellular metabolic activities. A brief description of antimicrobial mechanisms of action with a particular action site is presented later.

\section{Antibacterial Mechanism of Action}

EOs are mixtures of more than 60 different bioactive components (Ellse and Wall, 2014; Rehman et al., 2014). On the basis of their metabolic pathway of biosynthesis, the bioactive components are classified into (1) terpenoids with aromatic rings of monoterpenes, (2) sesquiterpenes, and (3) phenylpropanoids (Bakkali et al., 2008; Pavela and Benelli, 2016). All the different types of bioactive components have prominent antibacterial activity. The exact route of antibacterial activity of EOs cannot be confirmed due to the presence of a broad range of compounds in EOs exhibiting various mechanisms, affecting not only a particular target site but also different cell components. Herein, the possible mode of action of EOs and their principle components at different target sites of bacterial cells has been discussed.

\section{Effect on Cell Wall, Membrane Integrity, and Permeability}

The antibacterial efficacy of EOs is directly linked with their lipophilic nature. Cell wall and plasma membrane are reported as the primary target of EOs and bioactive constituents, leading to ultimate interaction with cellular polysaccharides, fatty acids, and phospholipids (Burt, 2004; Calo et al., 2015; Swamy et al., 2016). It has been observed that the EOs have more toxic effects on gram-positive food-contaminating bacteria as compared with gram-negative bacteria (Djihane et al., 2017). A thick layer of LPS covers the cell wall of gram-negative bacteria (more complexed in comparison with gram-positive ones), facilitating more resistance to the lipophilic nature of EOs, whereas the gram-positive bacterial cell wall made of the only peptidoglycan which is more susceptible to EOs and their components (Hsouna et al., 2011; Semeniuc et al., 2017). Moreover, in gram-negative bacteria, EOs slowly release via porin proteins of the outer membrane (Helander et al., 1998). Zhang et al. (2016) tested the effects of cinnamon EO against the foodborne pathogen E. coli and $S$. aureus. Furthermore, the authors reported a maximum dose of $1.0 \mathrm{mg} / \mathrm{ml}$ of cinnamon oil that significantly altered the synthesis of major components (as observed through scanning electron microscopy) involved in the biogenesis of bacterial cell walls. Moreover, EOs destabilize the membrane potential of cells by disrupting the plasma membrane integrity and permeability. Significant destabilization of membrane integrity and permeability with subsequent leakage of cellular ions $\mathrm{Na}^{+}$, $\mathrm{H}^{+}$, and $\mathrm{K}^{+}$) by $\mathrm{EO}$ fumigation suggested inactivation of vital metabolic systems (cellular respiration and ATP synthesis) in bacterial cells. Sokolik et al. (2018) reported the prime disorganization of membrane lipid fractions by thymol (at $0.25 \mathrm{mg} / \mathrm{ml}$ ), culminating in the destabilization of membrane permeability. Bouhdid et al. (2010) examined the changes in membrane permeability and potential of Pseudomonas aeruginosa and $S$. aureus at MIC concentration of cinnamon EO through propidium iodide and bis-oxonol staining. Diao et al. (2014) reported the severe effects of $F$. vulgare EO on the cell wall and cytoplasmic membrane of bacterial cells at $0.125 \mathrm{mg} / \mathrm{ml}$ due to disintegration of membrane permeability and integrity. In some cases, it has been observed that the principle components of EOs such as linalyl acetate, menthol, and thymol showed more antimicrobial efficacy in comparison with pure EOs due to more affectivity to break the lipid molecules of the bacterial cell membrane (Trombetta et al., 2005). In this context, Rudramurthy et al. (2016) observed the alternation in membrane fatty acid composition in different pathogenic bacteria by lipophilic compound carvacrol leading to disturbance in membrane permeability and fluidity.

\section{Effect on Quorum Sensing Signaling}

Cell-to-cell communication between bacterial cells is commonly known as quorum sensing. This communication is important for biofilm formation and antibiotic resistance to a wide range of foodborne bacteria. Therefore, the reduction of biofilm formation could be one of the important pathways for the prevention of bacterial infection (Saxena et al., 2019). EOs inhibit the expression of cell-to-cell communication and biofilm formation in different bacterial species (Snoussi et al., 2018). Moreover, the effect of EOs on the inhibition of biofilm formation in bacterial communities triggers the efficient breakdown of their sensing communications (Bouyahya et al., 2017). Luciardi et al. (2016) reported the inhibitory effect of Citrus reticulata EO (containing the monoterpene hydrocarbons such as limonene, $\gamma$-terinene, myrcene, and $\alpha$-pinene) against biofilm formation by $P$. aeruginosa at $0.1 \mathrm{mg} / \mathrm{ml}$ concentration. Mechanism of modulation of quorum sensing via EOs can be described by a phytochemical mixture of EO components leading to complex 
interaction with bacterial cell wall receptors, thus, reduced the reception of signal molecule as well as degraded the cell-to-cell signal communications (Camele et al., 2019).

\section{Effect on Leakage of Cytoplasmic Materials (DNA, RNA, and Proteins)}

Perturbation of plasma membrane integrity leading to efflux of DNA, RNA, and proteins after treatment with EOs in bacteria has been pointed out as a prime antimicrobial mechanism of action (Diao et al., 2014). Juniperus rigida EO at its MIC dose $(3.125 \mathrm{mg} / \mathrm{ml})$ showed antibacterial activity against Klebsiella pneumoniae by irreversible damage of plasma membrane followed by leakage of cellular proteins and $260-\mathrm{nm}$ absorbing materials (DNA and RNA). Han et al. (2020) tested the effect of limonene $(20 \mathrm{ml} / \mathrm{L})$ against Listeria monocytogenes and reported the sharp decrement in cellular protein and nucleic acid concentrations between 3 and $9 \mathrm{~h}$ of treatment due to disorganization in plasma membrane integrity facilitating leakage of major cytoplasmic materials.

\section{Effect on Proton Motive Force}

The antibacterial effect of EOs has been reported due to disorganization of the plasma membrane, potential interfering the electron transport system, the disintegration of the proton pump, and ATP depletion during biosynthesis (Bouyahya et al., 2019). Trans-cinnamaldehyde, an important bioactive component of cinnamon EO, exhibited a prominent role in restraining the membrane-associated enzymes and ATPase activity that ultimately reduced the cell viability (Vasconcelos et al., 2018). Moreover, the treatment of limonene against $L$. monocytogenes effectively inhibited the ATP content and activity of $\mathrm{Na}^{+} \mathrm{K}^{+}$ATPase and $\mathrm{Ca}^{++}$ATPase (Han et al., 2020). Figure 1 presents the antibacterial mechanism of EO action with their possible site of action.

Apart from mechanistic antimicrobial action, qualitative, and quantitative structure-activity relationship (SAR) of different compounds with specific enzymes and proteins displayed the pattern, selective bonding, and molecular linking (through functional groups and moieties) for effective inhibition. Hui et al. (2017) gained enough attention on SAR of thymol, eugenol, carvacrol, cinnamaldehyde, nerol, citral, linalool, geraniol, $\alpha-$ terpineol, and perillaldehyde for antimicrobial activity by targeting the 1-deoxy-D-xylulose 5-phosphate reductoisomerase (DXR) enzyme in E. coli. The binding capacity of the compounds was based on their lipophilicity, enabling them to create more structural effects on the plasma membrane and cell components. Moreover, the phenolic hydroxyl groups and delocalized electron in thymol, carvacrol, and eugenol showed the best effect on antimicrobial action by strong binding with the DXR enzyme. The aldehyde (perillaldehyde, cinnamaldehyde, and citral) and aromatic components ( $\alpha$-terpineol) did not result in any detectable inhibitory action against the DXR protein. Linalool, geraniol, and neral (allylic acyclic compound) displayed weak to medium binding with the DXR protein. The relative position of the $\mathrm{OH}$ group in thymol and carvacrol influences the antimicrobial effectiveness against gram-positive and gramnegative bacteria (Dorman and Deans, 2000). The ester group in bornyl acetate and geranyl cetate showed better antimicrobial effectiveness than the parent compounds. An alkenyl substituent (1 methylethenyl) facilitates maximum antibacterial activity as found in the case of limonene with respect to an alkyl substituent observed in the structure of $\mathrm{p}$-cymene. Another important factor responsible for the antibacterial activity is the stereochemistry of the chemical components. It has been critically observed that $\beta$-isomers are more active than the $\alpha$-isomer (e.g., $\alpha$-pinene), and cis-isomers were found inactive as compared with transisomer (e.g., nerol and geraniol). The degree of unsaturation and components containing methyl isopropyl cyclohexane rings (such as terpineol and terpinolene) showed more effectivity against bacterial infection (Saad et al., 2013).

\section{Antifungal Mechanism of Action}

The antifungal efficacy of EOs depends on the presence of different active constituents viz. monoterpenes, sesquiterpenes, phenols, aldehyde, and ketones, which are interacted to show synergistic, additive, and complementary effects (Soković et al., 2010). Terpenoids, alcohols, and phenolic terpenes in an oxygenated form precisely increase the antifungal activity of EOs (Bassolé and Juliani, 2012). Innumerable scientific reports have been published for wide-spectrum antifungal activity of EO in food, whereas the particular mechanism concerning the action sites has not yet been elucidated in detail (Rai et al., 2017; Basak and Guha, 2018; Arasu et al., 2019). Here, the possible mode of action of EOs and their principle components at different target sites of fungal cells has been discussed.

\section{Effect on Membrane Ergosterol}

Most of the hypotheses regarding the antifungal activity of EOs have been proposed due to their hydrophobic nature affecting ergosterol synthesis in the plasma membrane of fungi (Hyldgaard et al., 2012; Dwivedy et al., 2016). Ergosterol is specific to the fungal plasma membrane and responsible for maintaining membrane fluidity, viability, and integrity and helpful for the biogenesis of different membrane-bound enzymes (Pereira et al., 2015). In addition to direct destabilization of the plasma membrane, the effect of EOs on membrane ergosterol is another vital mechanism of antifungal action. Tian et al. (2012) studied dose-dependent inhibition of membrane ergosterol production in A. flavus after fumigation with A. graveolens $\mathrm{EO}$ and suggested plasma membrane as a key action site of the EO. Incubation of A. flavus cells at $0.25,0.5,0.75$, and $1.0 \mu \mathrm{l} / \mathrm{ml}$ of $A$. graveolens EO caused a reduction in membrane ergosterol content as observed 27.3, 48.4, 54.8, and 79.4\%, respectively. Similarly, Li et al. (2020) also revealed a significant reduction in membrane ergosterol content in A. flavus at I. verum EO concentration $>0.4$ $\mu \mathrm{l} / \mathrm{ml}$, and complete inhibition of ergosterol production was observed at $3.6 \mu \mathrm{l} / \mathrm{ml}$. Percent reduction of ergosterol content at $0.4,0.8,1.2,1.6,2.0,2.4,2.6,2.8,3.2$, and $3.6 \mu \mathrm{l} / \mathrm{ml}$ of $I$. verum $\mathrm{EO}$ was found 59, 67.38, 82.55, 90.64, 91.55, 94.47, 98.14, 99.14, and $100 \%$, respectively. They observed the decrement in ergosterol production was linked with interference in cell wall synthesis, which would further affect the A. flavus cellular morphology. Several EOs such as Rosmarinus officinalis, Piper betle, M. cardiaca, and Cistus ladanifer have been reported to 


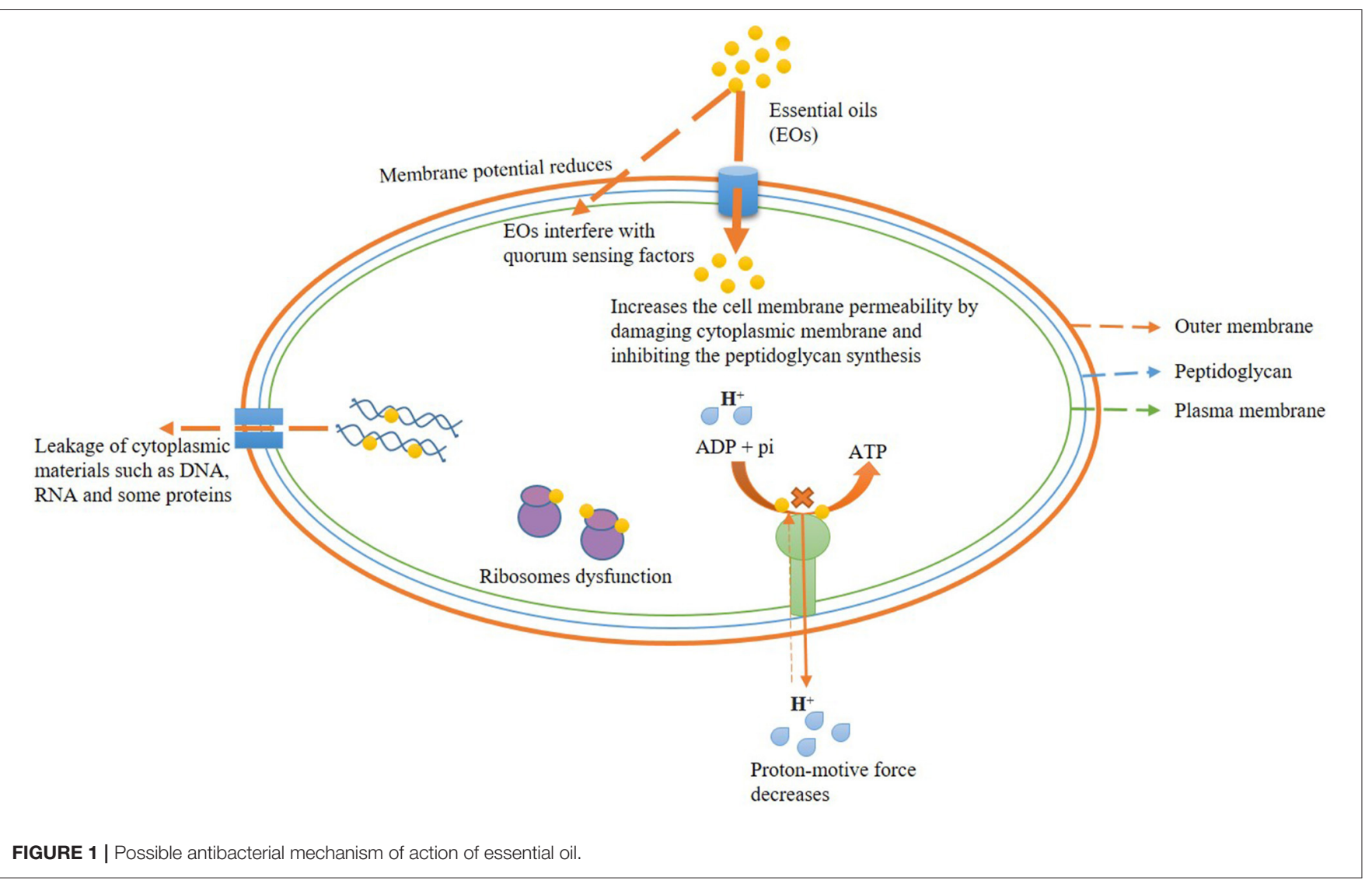

inhibit the ergosterol synthesis in fungal cells (Basak and Guha, 2017, Dwivedy et al., 2017; Upadhyay et al., 2018; da Silva Bomfim et al., 2020).

\section{Effect on Leakage of Cellular lons}

Destabilization of the plasma membrane by EOs ultimately leads to leakage of vital cellular ions such as $\mathrm{K}^{+}, \mathrm{Ca}^{2+}$, and $\mathrm{Mg}^{2+}$. This cytoplasmic imbalance of vital ions across the plasma membrane caused metabolic alteration and eventual cell death. Pimenta dioca EO caused membrane disorganization in A. flavus, facilitating the release of $\mathrm{K}^{+}, \mathrm{Ca}^{2+}$, and $\mathrm{Mg}^{2+}$ ions at sublethal and lethal concentrations of 1.25 and $2.5 \mu \mathrm{l} / \mathrm{ml}$, respectively (Chaudhari et al., 2020b). Kiran et al. (2016) reported the cell membrane-disrupting activity of $C$. zeylanicum EO in $A$. flavus, leading to efflux of $\mathrm{K}^{+}, \mathrm{Ca}^{2+}$, and $\mathrm{Mg}^{2+}$ ions in the extracellular medium.

\section{Effect on Mitochondrial Membrane Potential}

EOs have a prominent effect on plasma membrane permeability and fluidity, thus damaged the membrane protein structures. They can interact with cellular organelles such as mitochondria, ribosomes, endoplasmic reticulum, and Golgi body, resulting in a reduction of membrane potential, the disintegration of the proton pump, and ultimately inhibition of the ATPgenerating enzyme $\mathrm{H}^{+}$-ATPase, helpful for the development of electrochemical gradients and maintain the cellular $\mathrm{pH}$ across the membrane. Moreover, EOs also affect succinate dehydrogenase and malate dehydrogenase in respiratory processes (Bakkali et al., 2008; Hu et al., 2017). Nogueira et al. (2010) observed the ultrastructural changes on the plasma membrane and mitochondrial endomembrane system in $A$. flavus after fumigation with Ageratum conyzoides EO at 30 $\mathrm{mg} / \mathrm{ml}$. Ju et al. (2020) investigated the synergistic efficacy of eugenol and citral $\left(\mathrm{S}_{\mathrm{EC}}\right)$ on Penicillium roqueforti and demonstrated a significant rising in mitochondrial membrane potential, which further collapsed the cellular energy-based metabolic pathways. Moreover, disturbances in mitochondrial membrane potential hamper signaling pathways and key steps for cellular apoptosis.

\section{Effect on DNA and Gene Expression}

Nucleic acids (DNA and RNA) play an important role in vital cellular activities such as growth, development, and subsequent metabolic processes by transcriptional and translational regulations. Moreover, the expression of genetic materials governs the synthesis and metabolism of cellular proteins (Lappa et al., 2017). Therefore, normal growth and reproduction of fungal cells have been affected after fumigation with EOs and their components by damaging nuclear contents (El Khoury et al., 2016). Zhou et al. (2018) investigated the changes in transcriptome profile of differently expressed genes (DEGs) in Penicillium expansum by treatment with EO component decanal. The number of DEGs was increased along with the extension of the duration of fumigation 
with decanal due to the accumulation of cellular fungistatic components. Upregulation of DEGs was observed after longterm fumigation of $P$. expansum with decanal that further leads to generating cellular stress molecules culminating in cell death. Hu et al. (2021) demonstrated the antifungal activity of Perilla fruitscens EO against A. flavus by transcriptome analysis of DEGs involving amino acid metabolism, membrane permeability, oxidative stress, and spore development. A total of 5,914 DEGs were investigated; among them, 3,025 genes were upregulated, whereas 2,889 genes were downregulated with respect to EO treatment. They observed the downregulation of brlA and vosA gene expression after EO treatment, thereby suppressed the conidial germination and asexual reproduction in A. flavus. Moreover, the EO also caused downregulation of two different cell cycle regulatory genes viz. mihl (synthesize protein tyrosin phosphatase that promotes entry into $\mathrm{M}$ phase of mitosis by dephosphorylation reactions) and nimE (produce threonine/serine kinase for entry into mitotic phase) and collapsed the cell cycle regulatory pathways, thereby inhibited the cellular growth and metabolism. Figure 2 presents the diagram of an antifungal mechanism of action of $\mathrm{EO}$ with their possible site of action.

Different studies on the antifungal activity of EOs have reported the relationship between the chemical structure of different components and antifungal effectiveness. Basic order for antifungal effectivity of different groups of EO components is phenol $>$ alcohol $>$ aldehyde $>$ ketone $>$ ester $>$ hydrocarbon. Andrade et al. (2019) reported the better antifungal effectiveness of phenolic constituents due to the disintegration of membrane permeability. Ascaridole, a bicyclic monoterpene having a peroxide functional group isolated from Chenopodium ambrosoides EO, was found effective against postharvest pathogen Botrytis cineria due to destruction of the plasma membrane and inhibition of conidial germination (Pizzolitto et al., 2020). Voda et al. (2004) and Dambolena et al. (2012) demonstrated the variability in antifungal effectiveness by the compound having similar functional groups due to differences in the chemical properties such as electrostatic, steric effects, lipophilicity, and oxygenation in the functional groups. Kumar A. et al. (2020) reported in silico binding interaction of eugenol with Erg-28 gene responsible for the synthesis of ergosterol. SAR mediated the highest affinity bound positioning of eugenol, camphor, and estragol into the catalytic side of Erg28 protein observed with the lowest binding energy. Inhibition of Erg-28 protein function further led to hampering the production of ergosterol, which in turn disorganized the membrane rigidity, dynamicity, and viscosity. Das et al. (2020a) demonstrated the variability in the binding of different components viz. elemicin (phenylpropene), apiol (phenyl propanoid), $\alpha$-pinene, fenchone (monoterpenoid), and p-cymene (alkylbenzene) with key ergosterol-synthesizing enzyme lanosterol-14- $\alpha$-demethylase at various amino acid positions such as ILE 363, HSD 295, LEU 493, THR 110, TYR 120, and PHE 494 through hydrogen bonding. The binding of different components in the catalytic portion of lanosterol-14- $\alpha$-demethylase suggested the inside penetration and stereospatial alteration based on their chemical structures.

\section{Antimycotoxigenic Mechanism of Action}

In addition to antimicrobial activity, EOs strongly inhibit varieties of food-contaminating mycotoxins and their negative impact on food nutritional quality. It has also been observed that EOs significantly reduced the biosynthesis of mycotoxin in stored food commodities at lower doses as compared with fungal inhibition. This happens due to the exertion of different pathways interacted through gene transcript to mitigate the mycotoxin contamination. Oliveira et al. (2020b) investigated the anti-aflatoxigenic activity of clove and rosemary EOs based on the expression of regulatory genes of secondary metabolism in $A$. flavus viz. laeA, lipA (encode lipase), and metP (metalloprotease) that regulate the key enzymes for toxin synthesis. The laeA gene is important for the production of methyltransferase enzyme that exhibits a positive impact on aflatoxin biosynthesis in $A$. flavus. Additionally, the lipA and metP genes are involved in the production of lipase and metalloprotease, with a significant effect on fungal reproduction and conidiogenesis. All the tested genes were significantly downregulated in the presence of both the EO treatments. At $0.25 \mu \mathrm{l} / \mathrm{ml}$ of clove EO, the expression of metP, laeA, and lipA in A. flavus was reduced by 42.4 , 38.5 , and $81.5 \%$, respectively. The rosemary EO displayed maximum inhibition of metP (98.5\%), laeA (95.5\%), and lipA (98.4\%) gene expression at $5 \mu \mathrm{l} / \mathrm{ml}$. The authors also reported more effective inhibition of tested toxin biosynthesizing genes by clove EO as compared with the rosemary EO based on the availability of chemical constituents. El Khoury et al. (2016) suggested the active participation of rosemary, fennel, anise, chamomile, cardamom, and celery EOs for reducing the expression of acOTApks, laeA, acOTAnrps, acpks, and veA genes, which are involved in ochratoxin A biosynthesis in $A$. carbonarius. The authors reported the effects on ochratoxigenic gene expression at $1.0 \mu \mathrm{l} / \mathrm{ml}$ of different test EOs, and variability in their downregulating gene expression was affected by nature and chemical constituents of EOs. It has been observed that chamomile EO was more effective for the downregulation of all the target genes, whereas the rosemary, fennel, anise, cardamom, and celery EOs had a significant effect on specific genes involved in ochratoxin production. The downregulation of acpks gene by 96,50 , and $90 \%$ accompanied with $86.9,68.8$, and $53.7 \%$ inhibition of ochratoxin was observed for fennel, celery, and rosemary EOs, respectively. Anise and cardamom EOs had an equal effect of $80 \%$ for ochratoxin inhibition. In the case of the acOTApks gene, the rosemary EO had no significant impact on gene expression, whereas cardamom, fennel, anise, chamomile, and celery reduced the expression of genes by $86,99,81,88$, and $76 \%$, respectively. Chamomile, cardamom, and rosemary EOs have reduced the expression of the acOTAnrps gene by $80 \%$, whereas its expression was not regulated by celery, fennel, and anise EOs. For $v e A$ and $l a e A$ genes, the expression was downregulated by $90-92 \%$ and $71 \%$ for chamomile and rosemary EOs. Anise and celery EOs displayed negligible effect on veA and laeA gene expression, whereas cardamom EO had no significant effect on laeA gene expression. aflM is a vital regulatory gene involved in the biosynthesis of aflatoxins by modulating conversion of versicolorin A to dimethylsterigmatocystin, and aflQ, aflP, and aflO are involved in the production of aflatoxin 


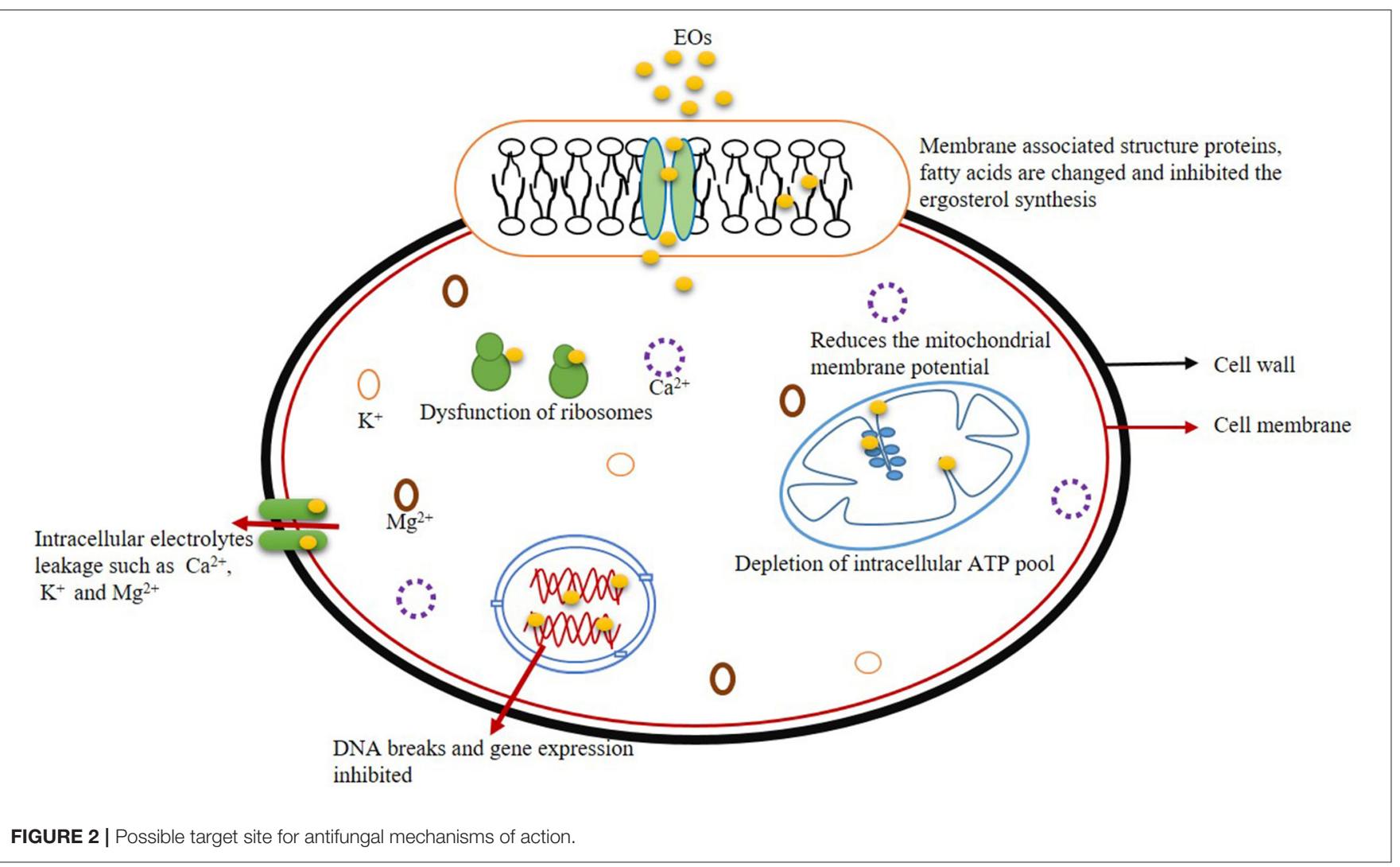

$\mathrm{B}_{1}$ from dimethylsterigmatocystin intermediate. Hu et al. (2017) investigated the effect of turmeric EO on inhibition of aflatoxin $\mathrm{B}_{1}$ production in $A$. flavus. The authors provided strong evidence for reducing the expression of aflR transcription factor in a dose-dependent manner within 5 days of treatment at 2, 4, and $8 \mu \mathrm{l} / \mathrm{ml}$ of turmeric EO. The EO had no positive effect on aflS transcription regulator enhancer. In contrast, the EO could downregulate the relative expression of aflO, aflP, aflM, aflD, and aflQ, leading to inhibition of aflatoxin $B_{1}$ production. Reduced expression of aflR, aftT, aflD, aflM, and aflP genes by cinnamaldehyde, eugenol, and citral has been suggested as a key mechanism for the downregulation of aflatoxin biosynthesis (Liang et al., 2015). The genes involving the synthesis of aflatoxin $\mathrm{B}_{1}$ have been clustered into the $75-\mathrm{kb}$ region of $A$. flavus genome, and aflR, aflT, aflD, aflM, and aflP actively participate in the synthesis of different enzymes viz. reductase, dehydrogenase, monooxygenase, and o-methyltransferase during polyketide to aflatoxin $B_{1}$ production. Hence, the downregulation of relative expressions of different genes evidenced the prominent antiaflatoxigenic mechanism of cinnamaldehyde, eugenol, and citral in A. flavus. Das et al. (2020a) described the molecular interaction of five bioactive components viz. p-cymne, fenchone, apiol, elemicin, and $\alpha$-pinene with polyketide synthase and Ver1 protein leading to inhibition of aflatoxin $\mathrm{B}_{1}$ biosynthesis. The authors demonstrated polyketide synthase and Ver-1 as the key enzyme that has a regulatory role in producing norsolinic acid anthrone and sterigmatocystin during aflatoxin $B_{1}$ synthesis.
Molecular simulation studies suggested the possible interaction of different components with polyketide synthase and Ver-1 protein by hydrogen bonding at different amino acids such as Val 242, Leu 491, Thr 182, Cys 554, and Glu 453. Moreover, the molecular interaction has also resulted in possible tight binding of EO components at the inner side of catalytic portions of polyketide synthase and Ver-1 protein as confirmed through more negative docking scores (kilocalorie per mole) and other binding energy indices (global energy, attractive Van der Waals force, and atomic contact energy). Cinnamaldehyde extracted from cinnamon EO played an important role in the downregulation of the transcriptional levels of ochratoxin biosynthesis by reduced expression of regulatory genes such as pks, nrps, veA, laeA, and velB in Aspergillus ochraceus (Wang et al., 2018). Oliveira et al. (2020b) addressed the molecular effects of thyme EO on the laeA gene in A. flavus and inhibited the production of aflatoxin $B_{1}$. Caceres et al. (2017) investigated that piperine-mediated inhibition of $\mathrm{AFB}_{1}$ biosynthesis by decreasing the transcript-level expression of the global regulator $v e A$ gene in A. flavus. Das et al. (2021a) revealed molecular homology of eugenol with aflatoxin biosynthetic gene ver-1, validating the molecular target site of action for $\mathrm{AFB}_{1}$ inhibition. Upadhyay et al. (2018) demonstrated the inhibition of methylglyoxal by C. ladanifer EO, which has been reported to induce $\mathrm{AFB}_{1}$ production by promoting the expression of aflR gene. Figure 3 represents the antimycotoxigenic mechanism of action of EOs and their components with a specific site of action. 


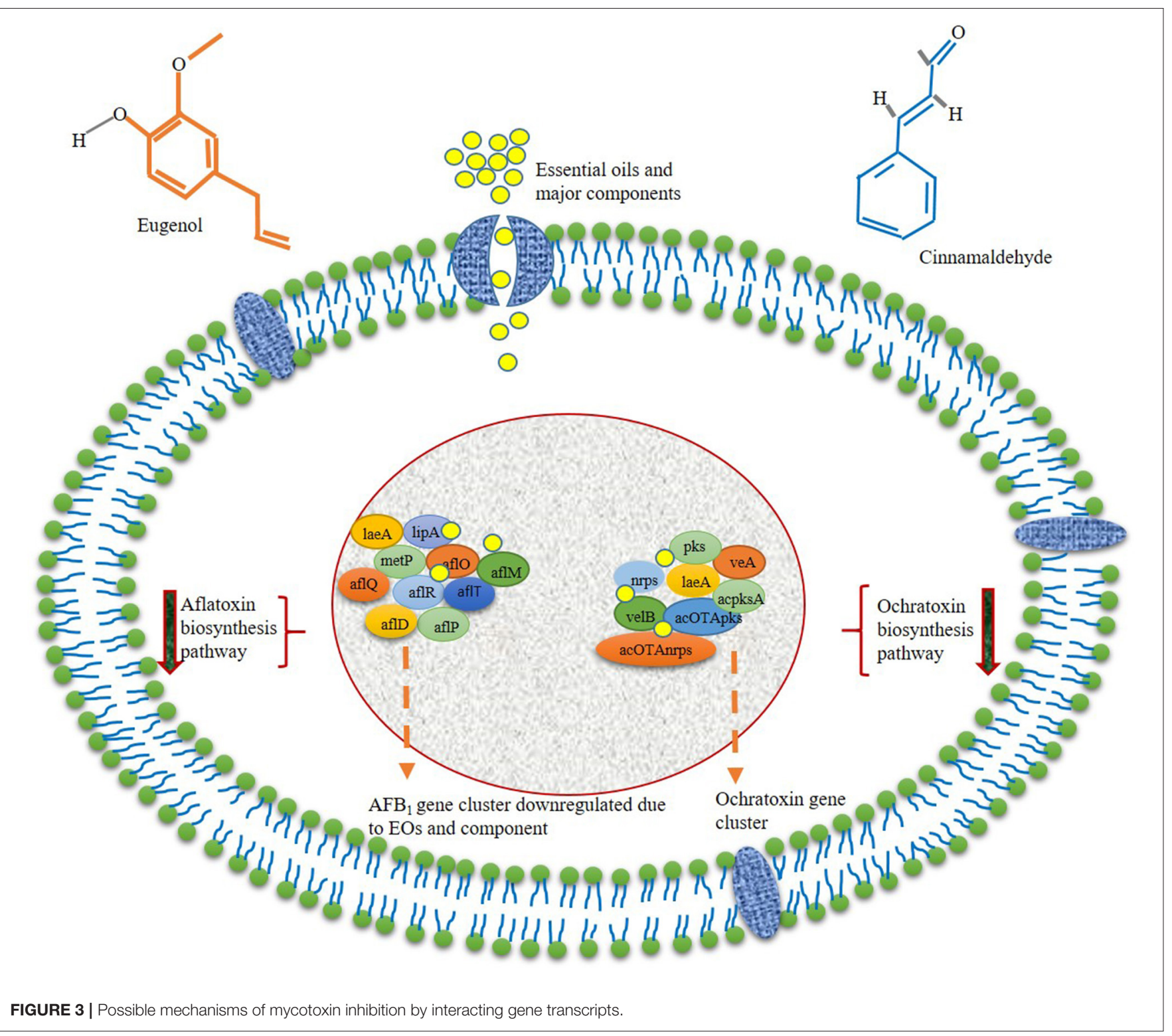

\section{APPLICATION OF ESSENTIAL OILS IN FOOD SYSTEM: SAFETY AND CHALLENGES}

Till now, a number of in vitro antimicrobial and antimycotoxigenic efficacy of EOs and components have been demonstrated; however, the in vivo practical efficacy of EO in food systems necessitates its wide application in food-based industrial sectors. Harmankaya and Vatansever (2017) reported the inhibitory effects of $R$. officinalis and $S$. aromaticum EOs against seven different gram-positive (Lactococcus lactis, S. aureus, L. monocytogenes, Brochotrix thermosphacta, Leuconostoc mesenteroides, Micrococcus luteus, and Lactobacillus casei) and six gram-negative (P. aeruginosa, E. coli, Shigella dysanteriae, S. typhimurium, Salmonella enteritidis, and Yersinia enterocolitica) pathogenic bacteria contaminating chicken meat and expanded the shelf-life for $24-48 \mathrm{~h}$. During the study, clove EO was found more effective than rosemary oil, whereas the application of clove and rosemary EO combinations displayed better antimicrobial efficiency for preservation and shelf life enhancement of poultry meat. de Sá Silva et al. (2019) evaluated the antimicrobial effectivity of Melaleuca alternifolia EO against the L. monocytogenes at a very low concentration in ground beef. L. monocytogenes was found extremely sensitive to the $\mathrm{EO}$, and the minimum inhibitory concentration and minimum bactericidal concentration were recorded as 0.10 and $0.15 \mu \mathrm{l} / \mathrm{ml}$, respectively. The authors also reported an increase in $\mathrm{pH}$ of control beef samples due to the breakdown of meat proteins to free amino acids and produced different amines after alkaline reactions, whereas the beef samples treated with the M. alternifolia $\mathrm{EO}$ maintained the $\mathrm{pH}$, which has been justified by elimination of infestation of spoilage bacteria and inhibition 
of toxin production in ground beef. Inhibitory effects of clove and cinnamon EOs against the infestation of Penicillium and Aspergillus in baked foods without influencing the organoleptic properties have been recently investigated by Ju et al. (2018). In research conducted by Arasu et al. (2019), the EO of Allium sativum significantly inhibited the infestation of $A$. niger and A. flavus in plum fruit and preserved its quality for 10 days of storage. During in vitro assay, the growth of $A$. niger and $A$. flavus was completely inhibited at 7.5 and $6.5 \mu \mathrm{g} / \mathrm{ml}$, whereas the in vivo application of A. sativum EO could require a 1.5fold higher concentration than the in vitro antifungal efficacy. A $50-80 \%$ reduction in A. niger infestation by A. sativum EO in plum fruit was observed, whereas the percent inhibition of A. flavus infestation was recorded between 20 and $55 \%$. Dwivedy et al. (2018) showed the in situ potency of I. verum EO in the complete protection of Pistacio seeds from fungal and aflatoxin $B_{1}$ contamination. BoŽik et al. (2017) showed complete inhibition of A. flavus, A. parasiticus, and A. clavatus in oats by lemongrass, oregano, and thyme EOs. Chein et al. (2019) investigated the efficacy of thyme, cinnamon, and lemongrass EOs to control the contamination of A. flavus and Penicillium citrinum at the lowest minimum inhibitory concentration of 40 $\mu \mathrm{l} / \mathrm{ml}$ in peanuts kernels. Omidbeygi et al. (2007) investigated the antifungal property of thyme and summer savory EOs against A. flavus in tomato paste at effective concentrations of 0.35 and $0.5 \mu \mathrm{g} / \mathrm{ml}$, respectively. In an experiment by Atif et al. (2020), it has been observed that Ocimum basilicum and Vetiveria zizanioides EOs displayed prominent synergistic efficacy for the protection of stored jack fruits (Artocarpus heterophyllus) against bacterial and fungal spoilage. Frazão et al. (2017) evaluated the effects of cambes seeds EOs for effective inhibition of growth and reproduction of B. cereus, $P$. aeruginosa, Bacillus subtilis, and $S$. aureus in postharvest stored mango fruits. Prominent inhibition of Salmonella contamination in grape berries by fumigation with lemongrass EO has been presented by Oh et al. (2017). Yassein et al. (2020) demonstrated the inhibition of mycotoxigenic fungi in baby foods such as cerelac, cornflakes, and milk powder by cumin and peppermint oil with restraining effects on aflatoxin and ochratoxin production. Tables 2,3 represent the antibacterial and antifungal activities in differed food products.

\section{APPLICATION OF ESSENTIAL OILS IN FOOD ANIMALS}

EOs also have a potential role in microbial safety and stability with consistent maintaining of nutritional quality of food animals based on its single inherent applications or by combinations of different preservative factors, simply represented as hurdles. The foodborne microorganisms would not be able to leap over the hurdles created by EOs in the fumigated foods; otherwise, spoilage of food items will occur. This hurdle deliberately improves the sensory attributes and microbial stability in foods. There is an increasing trend in applying hurdle technology in meat and dairy products throughout the world. Ishaq et al. (2021) investigated the multiple hurdle interventions developed by a combination of clove EO, ultraviolet light, and phage for efficient reduction of L. monocytogenes count on the surface of beef samples during refrigerated storage together with maintenance of nutritional quality and enhanced the shelf life. It was also observed that the hardness of the control beef samples after 15 days of storage was $41.89 \mathrm{~g}$, whereas the minimum value was recorded $(32.22 \mathrm{~g})$ for beef samples treated with a hurdle combination of $0.5 \%$ clove EO, bacteriophage, and ultraviolet treatment. Findings of the present investigation displayed a prominent increment in thiobarbituric acid (TBA) values $(1.57 \mathrm{mg} \mathrm{MDA} / \mathrm{kg}$ ) with a progression of 15 days of storage for control beef samples; however, the multiple hurdle combination could reduce the TBA value as recorded at $0.746 \mathrm{mg} \mathrm{MDA} / \mathrm{kg}$. Hence, the authors represented excellent microbial inactivation of EO-based hurdles for quality maintenance of stored slices of beef. In the case of poultry products, EOs are utilized in pre- and postharvest management strategies and help improve digestion and nutrient absorption. Additionally, the oregano and garlic EO in equal combination improved the sensory attributes of frozen chicken for 60 days (Kirkpinar et al., 2014).

A variety of preharvest strategies by using EO have been applied to reduce bacterial contamination in poultry feed. Improvement in digestibility of poultry feed after supplementing EO has been recently reported by Micciche et al. (2019). Brenes and Roura (2010) suggested the preharvest application of EO against pathogen colonization in the gastrointestinal tract of poultry birds. Arsi et al. (2014) examined the application of carvacrol, thymol, or their combination as a feed amendment to inhibit the colonization of Campylobacter jejuni. Cecal Campylobacter counts were observed by using Campylobacter line agar. At 0.25 and $2 \%$ concentrations of thymol, Campylobacter counts were reduced by 0.6 and $2 \log$ $\mathrm{CFU} / \mathrm{ml}$ of cecal content. Upadhyaya et al. (2015) investigated the effect of transcinnamaldehyde against infection of $S$. enteritidis in egg yolk and on egg shells. At 1 and $1.5 \%$ concentrations of transcinnamaldehyde, consistent infection of S. enteritidis was reduced in both the egg shell and egg yolk. During sensory analysis, 43 of the 108 panelists were identified eggs from transcinnamaldehyde-treated birds, whereas the remaining 65 panelists could not detect the treatments from control, thereby suggesting maximum acceptance and demonstrated the effectiveness of transcinnamaldehyde as a feeding supplement. Amerah et al. (2012) studied the effect of xylanase and a combination of thymol and cinnamaldehyde against horizontal transmission of Salmonella in broiler chickens. Supplementation of xylanase and a combination of thymol and cinnamaldehyde could reduce the number of Salmonella-positive cecal samples. Efficacy of eugenol and transcinnamaldehyde for reducing the contamination of Samonella enteritica in broiler chicken has been reported by Kollanoor-Johny et al. (2012). It was observed that $S$. enteritica count in the cecal sample of control birds was in the range of 6-7 log $\mathrm{CFU} / \mathrm{g}$, whereas $0.5 \%$ of transcinnamaldehyde and $1 \%$ of eugenol reduced the S. enteritica count by 4.3 and $2.6 \log \mathrm{CFU} / \mathrm{g}$, respectively. Wagle et al. (2017) demonstrated the application of $\beta$-resorcyclic acid as a potential antimicrobial food additive for the efficient reduction of Campylobacter colonization in broiler chickens. Average cecal Campylobacter colonization in control chicken was found as 
TABLE 2 | Essential oils and their active components against different food contaminating bacteria.

\begin{tabular}{|c|c|c|c|c|c|}
\hline $\begin{array}{l}\text { Food-contaminating } \\
\text { bacteria }\end{array}$ & $\begin{array}{l}\text { Major food } \\
\text { products }\end{array}$ & Essential oils & Major active ingredients & Effectivity & References \\
\hline Listeria monocytogenes & $\begin{array}{l}\text { Lighvan } \\
\text { cheese }\end{array}$ & Mentha spicata & $\begin{array}{l}\text { Carvone }(78.76 \%) \\
\text { Limonene }(11.5 \%)\end{array}$ & $\begin{array}{l}\text { Essential oil exhibited strong antimicrobial } \\
\text { effectivity against } L \text {. monocytogenes in Lighvan } \\
\text { cheese }\end{array}$ & Moosavy et al., 2013 \\
\hline Staphylococcus aureus & Sardine fish & Citrus aurantium & Limonene (77.37\%) & $\begin{array}{l}\text { Essential oil inhibited the growth of } \\
\text { experimentally inoculated S. aureus in Sardine. }\end{array}$ & Djenane, 2015 \\
\hline L. monocytogenes & Minced beef & $\begin{array}{l}\text { Pistacia lentiscus } \\
\text { Satureja montana }\end{array}$ & $\begin{array}{l}\beta \text {-myrcene }(15.18 \%) \\
\text { Carvacrol }(29.19 \%)\end{array}$ & $\begin{array}{l}\text { Combined action of essential oils against } L \text {. } \\
\text { monocytogenes during the storage period. }\end{array}$ & Djenane et al., 2011 \\
\hline $\begin{array}{l}\text { L. monocytogenes } \\
\text { Salmonella typhimurium }\end{array}$ & $\begin{array}{l}\text { Chicken } \\
\text { breast filet }\end{array}$ & Zingiber officinale & $\begin{array}{l}\alpha \text {-zingiberene }(24.96 \%) \text { and } \\
\beta \text {-sesquiphellandrene } \\
(12.74 \%)\end{array}$ & $\begin{array}{l}\text { Essential oil inhibited the growth of tested } \\
\text { microorganism in poultry meat }\end{array}$ & Noori et al., 2018 \\
\hline L. monocytogenes & $\begin{array}{l}\text { Iranian white } \\
\text { cheese }\end{array}$ & Mentha pulegium & $\begin{array}{l}\text { Pulegone (36.68\%), } \\
\text { Piperitenone (16.88\%) }\end{array}$ & $\begin{array}{l}\text { Reduction of growth of } L \text {. monocytogenes } \\
\text { during storage. }\end{array}$ & Sadeghi et al., 2016 \\
\hline Bacillus subtilis & Bread & Coriandrum sativum & $\beta$-linalool (66.07\%) & $\begin{array}{l}\text { Essential oil expressed antibacterial activity } \\
\text { against } B \text {. subtilis }\end{array}$ & Kačániová et al., 2020 \\
\hline $\begin{array}{l}\text { L. monocytogenes, } \\
\text { Salmonella enteritidis, } \\
\text { Yersinia enterocolitica, } \\
\text { Escherichia coli, and } \\
\text { Pseudomonas spp. }\end{array}$ & Vegetables & $\begin{array}{l}\text { Rosmarinus officinalis } \\
\text { Thymus vulgaris }\end{array}$ & $\begin{array}{l}\text { 1,8-cineole }(45.27 \%) \\
\text { Borneol }(12.94 \%) \\
\text { p-cymene }(39.18 \%) \\
\text { Thymol }(25.05 \%)\end{array}$ & $\begin{array}{l}\text { Essential oils and their combination reduce the } \\
\text { viable counts of bacteria in vegetables. }\end{array}$ & Iseppi et al., 2019 \\
\hline $\begin{array}{l}\text { E. coli } \\
\text { Salmonella } \\
\text { choleraesuis } \\
\text { L. monocytogenes } \\
\text { S. aureus }\end{array}$ & Leafy vegetables & Cymbopogon citratus & $\begin{array}{l}\text { Neral }(50 \%) \\
\text { Geranial }(35 \%)\end{array}$ & $\begin{array}{l}\text { Essential oil being more effective against tested } \\
\text { bacteria during in vivo and in vitro studies. }\end{array}$ & $\begin{array}{l}\text { Ortega Ramirez et al., } \\
2017\end{array}$ \\
\hline $\begin{array}{l}\text { S. aureus, E. coli, Bacillus } \\
\text { cereus, and S. typhimurium }\end{array}$ & $\begin{array}{l}\text { Cream-filled } \\
\text { cakes and } \\
\text { pastries }\end{array}$ & Cymbopogon citratus & $\begin{array}{l}\text { Neral }(39.0 \%) \text {, Geranial } \\
(33.3 \%)\end{array}$ & Essential oil as an effective antimicrobial agent & Vazirian et al., 2012 \\
\hline $\begin{array}{l}\text { Escherichia coli O157:H7 } \\
\text { L. monocytogenes }\end{array}$ & $\begin{array}{l}\text { Iranian white } \\
\text { cheese }\end{array}$ & Bunium persicum & Cuminaldehyde (11.4\%) & $\begin{array}{l}\text { Essential oil decreased bacterial growth and } \\
\text { extended the shelf life during } 45 \text { days storage } \\
\text { time compared to the control samples. }\end{array}$ & Ehsani et al., 2016 \\
\hline
\end{tabular}


TABLE 3 | Essential oils and their active components against different food contaminating fungi.

\begin{tabular}{|c|c|c|c|c|c|}
\hline $\begin{array}{l}\text { Food-contaminating } \\
\text { fungi }\end{array}$ & $\begin{array}{l}\text { Major food } \\
\text { products }\end{array}$ & Essential oils & Major active ingredients & Effectivity & References \\
\hline $\begin{array}{l}\text { Aspergillus ochraceus, } A \text {. } \\
\text { oryzae, A. fumigatus, and } A \text {. } \\
\text { parasiticus }\end{array}$ & Fish & Cymbopogon citratus & $\begin{array}{l}\text { Geranial (41.3\%), Neral } \\
(33.0 \%) \text {, Myrcene (10.4\%) }\end{array}$ & $\begin{array}{l}\text { Essential oil controlled the growth of Aspergillus } \\
\text { species in fermented fish. }\end{array}$ & Dègnon et al., 2019 \\
\hline A. flavus & Maize & Origanum majorana & $\begin{array}{l}\text { Terpinen-4-ol (28.92\%) } \\
\alpha \text {-terpineol (16.75\%) }\end{array}$ & $\begin{array}{l}\text { Essential oil exhibited antifungal and } \\
\text { antiaflatoxigenic activity to extend the shelf-life } \\
\text { of maize. }\end{array}$ & Chaudhari et al., 2020a \\
\hline Penicillium expansum & Bread & Cymbopogon citratus & Citral (62.58\%) & $\begin{array}{l}\text { The highest reduction was obtained at the } 750 \\
\mu l \text { of EO/Lair for } 21 \text { days storage. Inhibition was } \\
\text { also increased with increasing concentrations } \\
\text { of EO. }\end{array}$ & Mani López et al., 2018 \\
\hline A. flavus & Millets & Gaultheria fragrantissiuma & Methyl salicylate (98.04\%) & $\begin{array}{l}\text { Essential oil for antifungal and antiafaltoxigenic } \\
\text { preservation of millets }\end{array}$ & Kumar et al., 2018 \\
\hline A. flavus & Wheat & Laurus nobilis & 1,8 cineole (35.5\%) & $\begin{array}{l}\text { Increase shelf life by controlling food spoilage } \\
\text { molds }\end{array}$ & Belasli et al., 2020 \\
\hline $\begin{array}{l}\text { Botrytis cinereaA. niger } \\
\text { P. digitatum }\end{array}$ & Fruits & Cinnamomum spp. & Cinnamaldehyde (89.51\%) & $\begin{array}{l}\text { Essential oil for postharvest preservation of } \\
\text { vegetables and fruits. }\end{array}$ & Mousavian et al., 2018 \\
\hline A. flavus & $\begin{array}{l}\text { Avena sativa } \\
\text { seeds }\end{array}$ & $\begin{array}{l}\text { Ocimum sanctum } \\
\text { O. basilicum } \\
\text { O. canum }\end{array}$ & $\begin{array}{l}\text { Eugenol (53.39\%), Estragole } \\
(43.72 \%) \text {, Camphor } \\
(28.72 \%)\end{array}$ & $\begin{array}{l}\text { Synergistic activity of essential oils for the } \\
\text { preservation of seeds during storage }\end{array}$ & Kumar A. et al., 2020 \\
\hline $\begin{array}{l}\text { Botrytis spp. } \\
\text { Penicillium spp. And } \\
\text { Pilidiella granati }\end{array}$ & $\begin{array}{l}\text { Pomegranate } \\
\text { fruit }\end{array}$ & $\begin{array}{l}\text { Cinnamon verum } \\
\text { Cymbopogon citratus } \\
\text { Origanum vulgare }\end{array}$ & $\begin{array}{l}\text { Eugenol }(56.9 \%) \\
\text { Geranial }(41.4 \%) \\
\text { Carvacrol }(51.5 \%)\end{array}$ & $\begin{array}{l}\text { Chitosan-coated EOs can be used to control } \\
\text { postharvest fungal pathogens associated with } \\
\text { pomegranate fruit. }\end{array}$ & Munhuweyi et al., 2017 \\
\hline A. flavus & Maize grains & Zingiber officinale & $\begin{array}{l}\alpha \text {-zingiberene }(23.85 \%) \text { and } \\
\text { Geranial }(14.16 \%)\end{array}$ & $\begin{array}{l}\text { Essential oil for protection of maize against } \\
\text { ZOEO A. flavus. }\end{array}$ & Nerilo et al., 2020 \\
\hline Zygosaccharo-myces bailii & Salad & $\begin{array}{l}\text { Origanum vulgare } \\
\text { Eugenia spp. }\end{array}$ & $\begin{array}{l}\text { Carvacrol (63.1\%) } \\
\text { Eugenol }(85.5 \%)\end{array}$ & $\begin{array}{l}\text { Both essential oils exhibited good antifungal } \\
\text { activity with food products and maintained } \\
\text { sensory profile at the same time. }\end{array}$ & Ribes et al., 2019 \\
\hline A. flavus $L H P-P V-1$ & Dry fruits & Illicium verum & Anethole (89.12\%) & $\begin{array}{l}\text { Essential oil as antifungal, antiaflatoxigenic, and } \\
\text { antioxidant in dry fruits }\end{array}$ & Dwivedy et al., 2018 \\
\hline A. flavus & Rice & Myristica fragrans & $\begin{array}{l}\text { Elemicin (27.08\%), } \\
\text { Myristicine (21.29\%), and } \\
\text { Thujanol (18.55\%) }\end{array}$ & $\begin{array}{l}\text { Essential oil for the preservation of rice against } \\
\text { fungal infestation and aflatoxin } B_{1} \text { secretion }\end{array}$ & Das et al., 2020c \\
\hline $\begin{array}{l}\text { P. digitatum, P. italicum and } \\
\text { Geotrichum citri-aurantii }\end{array}$ & Citrus fruit & $\begin{array}{l}\text { Thymus leptobotrys } \\
\text { Thymus satureioides } \\
\text { Thymus broussonnetii } \\
\text { Thymus riatarum }\end{array}$ & $\begin{array}{l}\text { Carvacrol }(76.94 \%) \\
\text { Borneol }(27.71 \%) \\
\text { Camphor (46.17\%) } \\
\text { Carvacrol }(32.24 \%)\end{array}$ & $\begin{array}{l}\text { Essential oils for postharvest preservation of } \\
\text { citrus against fungal pathogens. }\end{array}$ & Boubaker et al., 2016 \\
\hline A. flavus & Maize & Curcuma longa & $\begin{array}{l}\text { ar-tumerone }(35.17 \%) \\
\text { Tumerone }(11.93 \%)\end{array}$ & $\begin{array}{l}\text { Essential oil for protection of maize against } A \text {. } \\
\text { flavus. }\end{array}$ & Hu et al., 2017 \\
\hline A. flavus & Spices & Ocimum gratissimum & $\begin{array}{l}\text { Methyl cinnamate }(48.29 \%) \\
\text { and } \gamma \text {-terpinene }(26.08 \%)\end{array}$ & $\begin{array}{l}\text { Essential oil to control the fungal- and } \\
\text { aflatoxin-mediated biodeterioration in spices. }\end{array}$ & Prakash et al., 2011 \\
\hline A. flavus & $\begin{array}{l}\text { Chickpea } \\
\text { seeds }\end{array}$ & Callistemon lanceolatus & 1,8-cineole (56\%) & $\begin{array}{l}\text { Essential oil as an antifungal agent for the } \\
\text { preservation of seeds during storage }\end{array}$ & Shukla et al., 2012 \\
\hline
\end{tabular}

$\vec{v}$ 
$7.5 \log \mathrm{CFU} / \mathrm{g}$, whereas supplementation of $\beta$-resorcyclic acid $(0.5$ and $1 \%)$ in feed reduced the chicken cecal Campylobacter population by 2.5 and $1.7 \log \mathrm{CFU} / \mathrm{g}$. Moreover, $\beta$-resorcyclic acid supplementation inhibited the expression of motility ( $\operatorname{mot} A$, $m o t B$, and $f l i A$ ), invasion, and adhesion genes ( $j l p A$ and $c i a B$ ) in C. jejuni. Application of EOs is most feasible to postharvest food products due to their prominent antimicrobial, antimycotoxin, and antioxidant activities; however, their application as a food supplement and an effective hurdle with consistent inhibition of bacterial colonization in the gastrointestinal tract of different food animals and mitigation of meat product based food contamination with widespread toxicity in humans develops a new insight with exciting potential for preharvest application of EOs. This preharvest application of EOs also has some limitations, such as rapid absorption of the EOs in the gastrointestinal tract leading to reduce effectivity. To overcome these limitations, EOs or bioactive components resistant to intestinal absorption can be applied.

Despite the excellent preservative potency of EOs in food safety, the volatility, hydrophobicity, and negative impact on food organoleptic properties drive their limited application in food and agricultural industries. Hence, specific delivery systems are required for a gradual release of EO aroma compatible with food-based applications. Nanoencapsulation, active packaging, and edible coating are common delivery strategies of EOs that help ease dispersion with consistent antimicrobial action and enhancement in food shelf life. Furthermore, controlled release behavior minimizes EO's impact on food organoleptic attributes and showed better diffusion kinetics.

\section{NANOENCAPSULATION OF ESSENTIAL OILS AND THEIR BIOACTIVE COMPONENTS FOR FOOD PRESERVATION: A GREEN NANOTECHNOLOGICAL APPROACH}

Currently, EO's nanoencapsulation has gained noticeable momentum in food industries and effective as a viable strategy to enhance the bioefficacy in postharvest applications. Nanoencapsulation is such a modern technological advancement in which the outer matrix polymer encloses the central core EOs by avoiding the sensitivity of degradation generated through external factors such as heating, oxidation, volatilization, and light. Moreover, the encapsulation reduces the size of particles with a greater surface-to-volume ratio, which would be more effective for improvement in efficacy, ease in handling, controlled release, and reduce the rate of evaporation. The selection of coating polymer is crucial for encapsulation; in fact, the biopolymer must be biocompatible and biodegradable and provide a suitable guarantee for targeted delivery. Different studies have reported that encapsulation not only develops an inert barrier to fluctuating environmental conditions but also provides maintenance of food nutritional quality. Different matrix polymers used as a carrier agent to encapsulate EOs are alginate, gelatin, chitosan, lecithin, zein, sodium alginate, $\beta$-cyclodextrin, starch, maltodextrin, gum arabic, whey protein, inulin, polylactide-co-glycolide, pectin cellulose, casein, collagen, soy proteins, and wheat gluten (Das et al., 2021b). A variety of nanoencapsulation techniques such as emulsification, nanoprecipitation, spray drying, ionic gelation, inclusion complexation, and coacervation have been greatly used to produce nanoparticles in the range of 10-1,000 nm. Ribes et al. (2017) demonstrated encapsulation of cinnamon EO into whey protein isolate using the polysorbate 80 and sunflower oil as an emulsifier and ripening inhibitor leading to the development of EO-loaded nanoemulsion. The nanoemulsion was found effective against $A$. niger during 7 days of incubation. At $0.25 \mu \mathrm{g} / \mathrm{g}$ of cinnamon EO-loaded nanoemulsion, complete inhibition of $A$. niger growth was observed, whereas, at the same concentration, the free EO inhibited $75 \%$ of mycelial growth. Interestingly, the nanoemulsion-based delivery system facilitates better interaction with microorganism target site and develops a new insight to maintain the in-product behavior. Liu and Liu (2020) described the fabrication of chitosan nanoemulsioncontaining thyme EO and thymol for significant protection of refrigerated pork against $S$. aureus and E. coli infection and also inhibited the formation of biofilm. Nanoencapsulation extended the shelf life of refrigerated pork for 6 days with improved color parameters. The diameters of the inhibition zone of $S$. aureus and E. coli by encapsulated thyme EO and thymol were found to be $16.33,17.33,14.67$, and $15.33 \mathrm{~mm}$, respectively. The authors observed better inhibition efficiency against grampositive bacteria as compared with gram-negative bacteria due to differences in the cell wall structure. The encapsulated thyme EO and thymol could inhibit biofilm formation, and the inhibitory percentages were recorded as $60.35,55.50,83.78$, and $83.64 \%$, respectively. Encapsulated thymol was found more effective for reduction in pork $\mathrm{pH}$ (6.64) as compared with the control (6.94), facilitating inhibition of spoilage bacteria that easily metabolize the nitrogen content of pork. Amiri et al. (2019) reported the application of starch films incorporated with Zataria multiflora EO nanoemulsion to protect the ground beef patties against microbial deterioration up to 20 days of storage, together with maintaining the organoleptic property and oxidative stability of the food system. The findings clearly represented the maintenance of peroxide value $(3.70 \mathrm{meq} / \mathrm{kg}$ of lipid), carbonyl content $(0.83 \mathrm{nmol} / \mathrm{mg}$ protein), and TBA reactive substance value ( $1.03 \mathrm{mg} \mathrm{MDA} / \mathrm{kg}$ sample) in ground beef patties by films containing the $Z$. multiflora EO nanoemulsion. The initial $\mathrm{pH}$ value of ground beef was found between 5.63 and 5.76, whereas during storage, an increasing trend in the $\mathrm{pH}$ of beef samples was observed. The ground meat samples coated by nanoemulsion films could reduce the $\mathrm{pH}$ and inhibit the multiplication of stationary phase microorganisms and protein deamination. The taste, color, odor, and overall acceptability of control beef samples were scored unacceptable, whereas higher scores of all the sensory attributes were assigned after fumigation with nanoemulsion. Cinnamon EO encapsulated into pullulan coatings considerably prolonged the shelf life of strawberries against bacteria and mold infestation, having an exciting potential as a food preservative. Das et al. (2020b) illustrated the encapsulation of $P$. anisum EO into chitosan nanomatrix in the form of nanoemulsion for the protection of stored rice against 
fungal and $\mathrm{AFB}_{1}$-mediated biodeterioration. The encapsulated $\mathrm{EO}$ at $\mathrm{MIC}(0.08 \mu \mathrm{l} / \mathrm{ml})$ and $2 \mathrm{MIC}(0.16 \mu \mathrm{l} / \mathrm{ml})$ doses inhibited the peroxidation of rice lipids and kept the MDA value up to $298.63 \mu \mathrm{M} / \mathrm{g} \mathrm{FW}$. The EO nanoemulsion could maintain the mineral (Ca, Mn, Fe, Zn, and $\mathrm{Mg}$ ) and macronutrient $(\mathrm{C}, \mathrm{H}, \mathrm{N}$, and $S$ ) content of rice for 1 year. Nanoencapsulation helped in the increment of the phenolic content of $P$. anisum $\mathrm{EO}$ with superior radical scavenging activity. Acceptable sensory properties (color, flavor, texture, and odor) were observed after fumigation of rice seeds by EO-loaded nanoemulsion, strengthening their utilization as a novel green food preservative. Improvement in fungitoxic efficacy of clove EO after encapsulation into chitosan nanoparticles against $A$. niger infestation in stored pomegranate has been recently reported by Hasheminejad et al. (2019). They suggested the controlled release of EO aroma (prerequisite criteria for shelf life extension of stored food) for 56 days. Furthermore, it was observed that the incidence of fungal decay occurred after 18 days in control pomegranate arils; however, it was delayed up to 60 days after fumigation with clove EO-loaded chitosan nanoparticle that could be associated with better effectivity of nanoparticles having a greater surfaceto-volume ratio altering the plasma membrane permeability and negative interaction in ergosterol synthesis that will lead to fungal cell death. Zhaveh et al. (2015) reported Cuminum cyminum EO incorporated into chitosan nanogel with improved antifungal activity against A. flavus. Kalagatur et al. (2018) conducted an experiment on encapsulation of Cymbopogon martini EO into chitosan nanocapsule and suggested the potency for inhibition of infestation of Fusarium graminearum and biosynthesis of zearalenone and deoxynivalenol in maize grain. The EO completely inhibited fungal growth and mycotoxin production at $0.9 \mu \mathrm{l} / \mathrm{ml}$, whereas chitosan-entrapped EO nanoparticle showed enhanced efficacy for inhibition of fungal growth and mycotoxin biosynthesis $(0.7 \mu \mathrm{l} / \mathrm{ml})$ in stored maize. A satisfactory regression model with good determination coefficients of 0.9694 and 0.9896 (for fungal growth inhibition), 0.9864 and 0.9793 (for inhibition of deoxynivalenol), and 0.9935 and 0.9873 (for inhibition of zearalenone) was observed for unencapsulated and nanoencapsulated EO, respectively. Moreover, the encapsulated EO was less prone to oxidative degradation due to the gradual release of components in a controlled manner. Table 4 represents the nanoencapsulated EO for efficient preservation of foodborne bacterial and fungal contamination with long-term efficacy.

Although several encapsulation strategies involving EOs for food protection have been developed, the understanding of different factors governing the rational application in the food system is not well-established. The nanoencapsulationbased delivery system is always concerned with the toxicity test to study the biological fate at the time of absorption, digestion, and excretion. A low $\mathrm{LD}_{50}$ value of nanoencapsulated $P$. anisum EOs as compared with the unencapsulated form has been reported by Das et al. (2020b). A similar report on reduction in $\mathrm{LD}_{50}$ value of chitosan-encapsulated $O$. majorana EO has recently been demonstrated by Chaudhari et al. (2020a), which could be due to the smaller size of nanoemulsionic particles containing a majority of EO droplets thus toxic to the mammalian system. Lower $\mathrm{LD}_{50}$ values represent a greater toxicity effect for different cellular processes and critical for practical applications in the food system. In addition to toxicity issues, several challenges of nanoencapsulation that need to be improved for further large scale applications in the real food system has been summarized as

- Searching for appropriate biocompatible, biodegradable, and environment-friendly generally recognized as a safe polymer for encapsulation of EOs and enhancement in bioefficacy.

- Improvement in efficiency process of encapsulation that reduces the utilization of energy.

- Searching for an alternative organic solvent, which is not safe for human consumption.

- Designing a multicompartment system for sustained delivery of different bioactive components (Shishir et al., 2018).

\section{ACTIVE PACKAGING AND COATING BASED DELIVERY OF ESSENTIAL OILS AND COMPONENTS IN FOOD}

Besides the direct application of nanoencapsulated $v s$. food protection, active packaging of food products by using EOs and different film-forming materials viz. low-density polyethylene (LDPE), polyvinyl alcohol (PVA), and ethylene vinyl alcohol $(\mathrm{EVOH})$ also develop the environmentally friendly route of food safety. The EO-based packaging of food commodities helps in the gradual diffusion of aroma through the micropore of the film surface and in close contact with the food items (Li et al., 2018). The effectivity of EO in the packaging system depends on the solubility of the lipophilic components into the food matrix. The low solubility of the components leads to a unilateral system having a low affinity to the food surface and a greater chance of microbial contamination, whereas in the case of the high solubility of the components, unconstrained free diffusion was observed, and considerably higher microbial resistance was reported. Reported the cellulose acetate film-containing rosemary EO at $50 \%(\mathrm{w} / \mathrm{w})$ of its concentration inhibited the coliform bacterial growth in chicken breast products. Active packaging of beef by chitosan filmcontaining lemon EO $(1 \% \mathrm{w} / \mathrm{w})$ exhibited a significant reduction in respiration rate and diminished the chances of microbial contamination, which can prolong the shelf life; however, somewhat alteration in food flavor was observed. Fresh beef coated with whey protein isolate and $1.5 \%$ oregano EO could inhibit microbial infestation and expand the shelf life of fresh beef during refrigeration (Zinoviadou et al., 2009). Modified atmospheric packaging of sweet cherry by applying menthol, eugenol, and thymol reduced the total number of molds, bacteria, and yeast from 2.1 to $1.5 \mathrm{lg} \mathrm{CFU} / \mathrm{g}$ after 16 days of treatment (Serrano et al., 2005). Demonstrated clove EO $(27.19 \% \mathrm{w} / \mathrm{w})$, and polyvinyl alcohol-mediated packaging of bread with good air permeability and effectively inhibited the A. niger growth with a resultant enhancement of shelf life. 
TABLE 4 | Nanoencapsulation of essential oil with special emphasis on food protection.

\begin{tabular}{|c|c|c|c|c|}
\hline Essential oil & Matrix polymer & $\begin{array}{l}\text { Nanoencapsulation } \\
\text { process }\end{array}$ & Food-based applications & References \\
\hline Cymbopogon martini & Chitosan & lonic gelation & $\begin{array}{l}\text { Protection of maize grain against Fusarium graminearum } \\
\text { and secretion of zearalenone and deoxynivalenol }\end{array}$ & Kalagatur et al., 2018 \\
\hline Clove essential oil & Chitosan & & $\begin{array}{l}\text { Protection of pomegranate against fungi viz. Aspergillus } \\
\text { niger infestation }\end{array}$ & $\begin{array}{l}\text { Hasheminejad et al., } \\
2019\end{array}$ \\
\hline $\begin{array}{l}\text { Cardamom essential } \\
\text { oil }\end{array}$ & Chitosan & & $\begin{array}{l}\text { Antibiotic-resistant bacterial pathogens viz. E. coli and S. } \\
\text { aureus }\end{array}$ & Jamil et al., 2016 \\
\hline Tarragon essential oil & Chitosan and gelatin & & $\begin{array}{l}\text { Treatment of encapsulated essential oil preserve the } \\
\text { quality of pork slices }\end{array}$ & Zhang et al., 2020 \\
\hline Coriandrum sativum & Chitosan & & Encapsulation preserves the quality of rice during storage & Das et al., 2019b \\
\hline Cinnamon essential oil & $\beta$-cyclodextrin & Inclusion complex & $\begin{array}{l}\text { Antimicrobial food packaging agent against the infection } \\
\text { of } S \text {. aureus and E. coli }\end{array}$ & Wen et al., 2016 \\
\hline Litsea cubeba & $\beta$-cyclodextrin & & $\begin{array}{l}\text { Fungitoxic potentiality against Penicillium digitatum, } P \text {. } \\
\text { italicum, and Geotrichum citriaurantii in postharvest } \\
\text { citrus fruit }\end{array}$ & Wang et al., 2020 \\
\hline Melaleuca alternifolia & $\beta$-cyclodextrin & & Antimicrobial packaging to preserve the quality of beef & Cui et al., 2018 \\
\hline Orange essential oil & $\beta$-cyclodextrin and zein & & Prevention of microbial and mold spoilage in cakes & Kringel et al., 2020 \\
\hline Pimenta dioca & Chitosan/k-carageenan & $\begin{array}{l}\text { Complex } \\
\text { coacervation }\end{array}$ & $\begin{array}{l}\text { Antimicrobial activity against B. subtilis, B. cereus, and } \\
\text { Candida utilis in food }\end{array}$ & Dima et al., 2014 \\
\hline Cymbopogon citratus & $\begin{array}{l}\text { Polyvinylalcohol crosslinked } \\
\text { glutaraldehyde }\end{array}$ & & Antimicrobial activity against $E$. coli ATCC25922 & Leimann et al., 2009 \\
\hline Thymus vulgaris & $\begin{array}{l}\text { Sodium casein and } \\
\text { maltodextrin }\end{array}$ & Spray drying & $\begin{array}{l}\text { Natural food preservative of hamburger-like meat } \\
\text { products against infection of } S \text {. aureus, Listeria } \\
\text { monocytogenes, and } E \text {. coli }\end{array}$ & Radünz et al., 2020 \\
\hline Lavandula hybrida & Soybean lecithin & & Inhibit the E. coli contamination in food products & Varona et al., 2013 \\
\hline Eugenol & $\begin{array}{l}\text { Whey protein isolate, } \\
\text { maltodextrin, and lecithin }\end{array}$ & & Inhibitory activity against Listeria innocua and $E$. coli & Talón et al., 2019 \\
\hline $\begin{array}{l}\text { Oregano essential oil } \\
\text { Lavender essential oil } \\
\text { Cinnamon essential oil } \\
\text { Citral } \\
\text { Menthone }\end{array}$ & Starch & & $\begin{array}{l}\text { Inhibition of food-contaminating bacteria such as } S \text {. } \\
\text { aureus and E. coli }\end{array}$ & Qiu et al., 2017 \\
\hline Cinnamon essential oil & $\begin{array}{l}\text { Chitosan and whey protein } \\
\text { isolate }\end{array}$ & & $\begin{array}{l}\text { Long-term antibacterial activity against foodborne } \\
\text { bacteria Staphylococcus putrifaciens, P. fragi, S. aureus, } \\
\text { and E. coli }\end{array}$ & Yang et al., 2020 \\
\hline Syzygium aromaticum & Sodium alginate & Emulsification & $\begin{array}{l}\text { In vivo bactericidal effect against foodborne pathogens } \\
\text { E. coli, S. typhimurium, and S. aureus }\end{array}$ & Radünz et al., 2019 \\
\hline Cinnamaldehyde & Medium chain triglycerides & & Antimicrobial activity against $S$. aureus and $E$. coli & Tian et al., 2016 \\
\hline $\begin{array}{l}\text { Schinus } \\
\text { terebinthifolius }\end{array}$ & Maltodextrin & & $\begin{array}{l}\text { Inhibition of foodborne bacteria such as } B \text {. subtilis, } L \text {. } \\
\text { innocua, and } L \text {. monocytogenes }\end{array}$ & $\begin{array}{l}\text { Locali-Pereira et al., } \\
2020\end{array}$ \\
\hline
\end{tabular}

In addition to active packaging, several reports are available on the edible coating of EOs regarding their antimicrobial effectiveness against foodborne pathogens. The coating is altogether different from films and applied in liquid form on the food to be coated. Sánchez-González et al. (2011) reported edible hydroxypropylmethylcellulose and chitosan coating with bergamot EO for postharvest preservation of table grapes during cold storage with effective antimicrobial activity and reduced rate of respiration. The EO-based edible coating also has minimal impact on food organoleptic attributes and enhanced the antimicrobial activity (Donsì et al., 2011; Donsì and Ferrari, 2016). Different types of edible coating viz. polysaccharide, protein, lipid, and composite coating involving varieties of EOs showed prominent inhibitory activity against growth and 
reproduction of several food-contaminating bacteria such as $L$. monocytogenes, E. coli, and S. aureus. Chauhan et al. (2011) demonstrated the Aloe vera gel, lemon EO, and shellac-mediated coating of apple slices to prevent microbial infection and could mitigate the rate of ethylene during storage and inhibit the oxidase activity with consistent maintaining the apple color. Guerra et al. (2016) examined the effect of chitosan, Mentha piperata, and M. villosa EO-mediated coating of grapes to inhibit the fungal infestation during storage. The coated grapes received a better score for acceptance during sensory analysis in color, flavor, aftertaste, and texture. Rojas-Graü et al. (2007) reported the effect of edible coating of apple with oregano, lemongrass EO, and vanillin incorporated into puree-alginate. The coating significantly diminished the growth of molds, yeast, and psychrophilic bacteria. Oregano and lemongrass EO $(1.5$ and $1.0 \% \mathrm{w} / \mathrm{w})$ with a coating $(0.5 \% \mathrm{w} / \mathrm{w})$ strongly reduced the infection of $L$. innocua (4 log reduction) in apple pieces.

\section{CONCLUSION}

The present review discusses the multifaceted applications of EOs in food preservation and develops its exciting potential as a novel green alternative to the harmful effects of synthetic preservatives. Being naturally used in food with less residual toxicity and minimal adverse effects, EOs are exempted from toxicity aspects and accepted to be safe for preservation purposes. However, the application of EOs as food preservatives have some limitations such as negative effect on organoleptic properties, volatility, low stability, and low water solubility, which prevent their large scale practical utilization. Different delivery strategies such as nanoencapsulation, active packaging, and polymerbased coating involving EOs are promising systems for better antimicrobial, antifungal, and antimycotoxigenic effectiveness in

\section{REFERENCES}

Amerah, A. M., Mathis, G., and Hofacre, C. L. (2012). Effect of xylanase and a blend of essential oils on performance and Salmonella colonization of broiler chickens challenged with Salmonella Heidelberg. Poult. Sci. 91, 943-947. doi: 10.3382/ps.2011-01922

Amiri, E., Aminzare, M., Azar, H. H., and Mehrasbi, M. R. (2019). Combined antioxidant and sensory effects of corn starch films with nanoemulsion of Zataria multiflora essential oil fortified with cinnamaldehyde on fresh ground beef patties. Meat Sci. 153, 66-74. doi: 10.1016/j.meatsci.2019.03.004

Amiri, N., Afsharmanesh, M., Salarmoini, M., Meimandipour, A., Hosseini, S. A., and Ebrahimnejad, H. (2020). Effects of nanoencapsulated cumin essential oil as an alternative to the antibiotic growth promoter in broiler diets. Journal of Applied Poultry Research. 29, 875-885. doi: 10.1016/j.japr.2020.08.004

Andrade, J. C., da Silva, A. R. P., Freitas, M. A., de Azevedo Ramos, B., Freitas, T. S., Franz de Assis, G., et al. (2019). Control of bacterial and fungal biofilms by natural products of Ziziphus joazeiro Mart. (Rhamnaceae). Comp. Immunol. Microbiol. Infect. Dis. 65, 226-233. doi: 10.1016/j.cimid.2019.06.006

Arasu, M. V., Viayaraghavan, P., Ilavenil, S., Al-Dhabi, N. A., and Choi, K. C. (2019). Essential oil of four medicinal plants and protective properties in plum fruits against the spoilage bacteria and fungi. Indus. Crops Products 133, 54-62. doi: 10.1016/j.indcrop.2019.03.018

Arsi, K., Donoghue, A. M., Venkitanarayanan, K., Kollanoor-Johny, A., Fanatico, A. C., Blore, P. J., et al. (2014). The efficacy of the natural plant extracts, thymol food systems without compromising their nutritional qualities. To date, practical application of encapsulation and coatingbased EO delivery approach in the real food system are scarce. Considering the food-based industrial relevance of EOs, possible toxicological studies in a mammalian system and the market value of EOs need to be further investigated for their potential application as eco-friendly smart green preservatives in the food and agriculture industries.

\section{AUTHOR CONTRIBUTIONS}

AM wrote the manuscript and prepared the figures, with contributions from JP and SD. AD conceptualized the idea and supervised the manuscript preparation. All authors reviewed the manuscript and gave their approval for its submission in its current form.

\section{FUNDING}

This work was supported by University Grant Commission, New Delhi, India with minor grant. Authors were also thankful to the Council of Scientific and Industrial Research (CSIR) [09/013(0774)/2018-EMR-I].

\section{ACKNOWLEDGMENTS}

The authors are thankful to UGC, New Delhi, for financial assistance as a Start-Up grant. JP and SD are thankful to the Council of Scientific and Industrial Research, New Delhi, India, for a research fellowship. The authors are also thankful to the Head of the Department of Botany, Banaras Hindu University, ISLS, DST-FIST, DST-PURSE, and Institute of Eminence (IoE) Cell, Banaras Hindu University, Varanasi, Uttar Pradesh, India, for providing necessary facilities. and carvacrol against Campylobacter colonization in broiler chickens. J. Food Saf. 34, 321-325. doi: 10.1111/jfs. 12129

Atif, M., Ilavenil, S., Devanesan, S., AlSalhi, M. S., Choi, K. C., Vijayaraghavan, P., et al. (2020). Essential oils of two medicinal plants and protective properties of jack fruits against the spoilage bacteria and fungi. Indus. Crops Prod. 147:112239. doi: 10.1016/j.indcrop.2020.112239

Bakkali, F., Averbeck, S., Averbeck, D., and Idaomar, M. (2008). Biological effects of essential oils-a review. Food Chem. Toxicol. 46, 446-475. doi: 10.1016/j.fct.2007.09.106

Baldim, I., Tonani, L., von Zeska Kress, M. R., and Oliveira, W. P. (2019). Lippia sidoides essential oil encapsulated in lipid nanosystem as an anti-Candida agent. Indus. Crops Prod. 127, 73-81. doi: 10.1016/j.indcrop.2018.10.064

Basak, S., and Guha, P. (2017). Use of predictive model to describe sporicidal and cell viability efficacy of betel leaf (Piper betle L.) essential oil on Aspergillus flavus and Penicillium expansum and its antifungal activity in raw apple juice. $L W T$ 80, 510-516. doi: 10.1016/j.lwt.2017.03.024

Basak, S., and Guha, P. (2018). A review on antifungal activity and mode of action of essential oils and their delivery as nano-sized oil droplets in food system. J. Food Sci. Technol. 55, 4701-4710. doi: 10.1007/s13197-018-3394-5

Bassolé, I. H. N., and Juliani, H. R. (2012). Essential oils in combination and their antimicrobial properties. Molecules 17, 3989-4006. doi: 10.3390/molecules17043989

Belasli, A., Ben Miri, Y., Aboudaou, M., Aït Ouahioune, L., Montañes, L., Ariño, A., et al. (2020). Antifungal, antitoxigenic, and antioxidant activities of the essential 
oil from laurel (Laurus nobilis L.): potential use as wheat preservative. Food Sci. Nutr. 8, 4717-4729. doi: 10.1002/fsn3.1650

Bhavaniramya, S., Vishnupriya, S., Al-Aboody, M. S., Vijayakumar, R., Baskaran, D., et al. (2019). Role of essential oils in food safety: antimicrobial and antioxidant applications. Grain Oil Sci. Technol. 2, 49-55. doi: 10.1016/j.gaost.2019.03.001

Bondi, M., Lauková, A., de Niederhausern, S., Messi, P., and Papadopoulou, C. (2017). Natural preservatives to improve food quality and safety. J. Food Qual. 2017:1090932. doi: 10.1155/2017/1090932

Boubaker, H., Karim, H., El Hamdaoui, A., Msanda, F., Leach, D., Bombarda, I., et al. (2016). Chemical characterization and antifungal activities of four Thymus species essential oils against postharvest fungal pathogens of citrus. Indus. Crops Prod. 86, 95-101. doi: 10.1016/j.indcrop.2016.03.036

Bouhdid, S., Abrini, J., Amensour, M., Zhiri, A., Espuny, M. J., and Manresa, A. (2010). Functional and ultrastructural changes in Pseudomonas aeruginosa and Staphylococcus aureus cells induced by Cinnamomum verum essential oil. J. Appl. Microbiol. 109, 1139-1149. doi: 10.1111/j.1365-2672.2010.04740.x

Bouhdid, S., Skali, S. N., Idaomar, M., Zhiri, A., Baudoux, D., Amensour, M., et al. (2008). Antibacterial and antioxidant activities of Origanum compactum essential oil. Afr. J. Biotechnol. 7, 1563-1570.

Bouyahya, A., Abrini, J., Dakka, N., and Bakri, Y. (2019). Essential oils of Origanum compactum increase membrane permeability, disturb cell membrane integrity, and suppress quorum-sensing phenotype in bacteria. J. Pharma. Anal. 9, 301-311. doi: 10.1016/j.jpha.2019.03.001

Bouyahya, A., Dakka, N., Et-Touys, A., Abrini, J., and Bakri, Y. (2017). Medicinal plant products targeting quorum sensing for combating bacterial infections. Asian Pac. J. Trop. Med. 10, 729-743. doi: 10.1016/j.apjtm.2017.07.021

BoŽik, M., Císarová, M., Tančinová, D., Kourimská, L., Hleba, L., and Klouček, P., et al. (2017). Selected essential oil vapours inhibit growth of Aspergillus spp. in oats with improved consumer acceptability. Indus. Crops Prod. 98, 146-152. doi: 10.1016/j.indcrop.2016.11.044

Brahmi, F., Abdenour, A., Bruno, M., Silvia, P., Alessandra, P., Danilo, F., et al. (2016). Chemical composition and in vitro antimicrobial, insecticidal and antioxidant activities of the essential oils of Mentha pulegium L. and Mentha rotundifolia (L.) Huds growing in Algeria. Indus. Crops Prod. 88, 96-105. doi: $10.1016 /$ j.indcrop.2016.03.002

Brenes, A., and Roura, E. (2010). Essential oils in poultry nutrition: main effects and modes of action. Anim. Feed Sci. Technol. 158, 1-14. doi: 10.1016/j.anifeedsci.2010.03.007

Burt, S. (2004). Essential oils: their antibacterial properties and potential applications in foods-a review. Int. J. Food Microbiol. 94, 223-253. doi: 10.1016/j.ijfoodmicro.2004.03.022

Caceres, I., El Khoury, R., Bailly, S., Oswald, I. P., Puel, O., and Bailly, J. D. (2017). Piperine inhibits aflatoxin B1 production in Aspergillus flavus by modulating fungal oxidative stress response. Fungal Genet. Biol. 107, 77-85. doi: 10.1016/j.fgb.2017.08.005

Callan, N. W., Johnson, D. L., Westcott, M. P., and Welty, L. E. (2007). Herb and oil composition of dill (Anethum graveolens L.): effects of crop maturity and plant density. Indus. Crops Prod. 25, 282-287. doi: 10.1016/j.indcrop.2006.12.007

Calo, J. R., Crandall, P. G., O’Bryan, C. A., and Ricke, S. C. (2015). Essential oils as antimicrobials in food systems-A review. Food Control 54, 111-119. doi: 10.1016/j.foodcont.2014.12.040

Camele, I., Elshafie, H. S., Caputo, L., and De Feo, V. (2019). Antiquorum sensing and antimicrobial effect of mediterranean plant essential oils against phytopathogenic bacteria. Front. Microbiol. 10:2619. doi: 10.3389/fmicb.2019.02619

Caputo, L., Reguilon, M. D., Mińarro, J., De Feo, V., and RodriguezArias, M. (2018). Lavandula angustifolia essential oil and linalool counteract social aversion induced by social defeat. Molecules 23:2694. doi: 10.3390/molecules 23102694

Chagas, E. C., Majolo, C., Monteiro, P. C., Oliveira, M. R. D., Gama, P. E., and Bizzo, H. R. (2020). Composition of essential oils of Mentha species and their antimicrobial activity against Aeromonas spp. J. Essent. Oil Res. 32, 209-215. doi: 10.1080/10412905.2020.1741457

Chaudhari, A. K., Singh, V. K., Das, S., and Dubey, N. K. (2021). Nanoencapsulation of essential oils and their bioactive constituents: a novel strategy to control mycotoxin contamination in food system. Food Chem. Toxicol. 149:112019. doi: 10.1016/j.fct.2021.112019
Chaudhari, A. K., Singh, V. K., Das, S., Prasad, J., Dwivedy, A. K., et al. (2020a). Improvement of in vitro and in situ antifungal, AFB1 inhibitory and antioxidant activity of Origanum majorana L. essential oil through nanoemulsion and recommending as novel food preservative. Food Chem. Toxicol. 143:111536. doi: 10.1016/j.fct.2020.111536

Chaudhari, A. K., Singh, V. K., Dwivedy, A. K., Das, S., Upadhyay, N., Singh, A., et al. (2020b). Chemically characterised Pimenta dioica (L.) Merr. essential oil as a novel plant based antimicrobial against fungal and aflatoxin B1 contamination of stored maize and its possible mode of action. Nat. Prod. Res. 34, 745-749. doi: 10.1080/14786419.2018.1499634

Chauhan, O. P., Raju, P. S., Singh, A., and Bawa, A. S. (2011). Shellac and aloegel-based surface coatings for maintaining keeping quality of apple slices. Food Chem. 126, 961-966. doi: 10.1016/j.foodchem.2010.11.095

Chein, S. H., Sadiq, M. B., and Anal, A. K. (2019). Antifungal effects of chitosan films incorporated with essential oils and control of fungal contamination in peanut kernels. J. Food Process. Preserv. 43:e14235. doi: 10.1111/jfpp.14235

Cui, H., Bai, M., and Lin, L. (2018). Plasma-treated poly (ethylene oxide) nanofibers containing tea tree oil/beta-cyclodextrin inclusion complex for antibacterial packaging. Carbohydr. Polymers 179, 360-369. doi: 10.1016/j.carbpol.2017.10.011

Cunha, B. G., Duque, C., Caiaffa, K. S., Massunari, L., Catanoze, I. A., Dos Santos, D. M., et al. (2020). Cytotoxicity and antimicrobial effects of citronella oil (Cymbopogon nardus) and commercial mouthwashes on S. aureus and C. albicans biofilms in prosthetic materials. Arch. Oral Biol. 109:104577. doi: 10.1016/j.archoralbio.2019.104577

da Silva Bomfim, N., Kohiyama, C. Y., Nakasugi, L. P., Nerilo, S. B., Mossini, S. A. G., Romoli, J. C. Z., et al. (2020). Antifungal and antiaflatoxigenic activity of rosemary essential oil (Rosmarinus officinalis L.) against Aspergillus flavus. Food Additi. Contam. 37, 153-161. doi: 10.1080/19440049.2019.1678771

Dahmani-Hamzaoui, N., and Baaliouamer, A. (2010). Chemical composition of Algerian Artemisia herba-alba essential oils isolated by microwave and hydrodistillation. J. Essent. Oil Res. 22, 514-517. doi: $10.1080 / 10412905.2010 .9700386$

Dambolena, J. S., López, A. G., Meriles, J. M., Rubinstein, H. R., and Zygadlo, J. A. (2012). Inhibitory effect of 10 natural phenolic compounds on Fusarium verticillioides. A structure-property-activity relationship study. Food Control 28, 163-170. doi: 10.1016/j.foodcont.2012.05.008

Das, S., Kumar Singh, V., Kumar Dwivedy, A., Kumar Chaudhari, A., Upadhyay, N., Singh, A., et al. (2020c). Assessment of chemically characterised Myristica fragrans essential oil against fungi contaminating stored scented rice and its mode of action as novel aflatoxin inhibitor. Nat. Prod. Res. 34, 1611-1615. doi: 10.1080/14786419.2018.1519826

Das, S., Singh, V. K., Dwivedy, A. K., Chaudhari, A. K., and Dubey, N. K. (2020a). Exploration of some potential bioactive essential oil components as green food preservative. LWT 137:110498. doi: 10.1016/j.lwt.2020.110498

Das, S., Singh, V. K., Dwivedy, A. K., Chaudhari, A. K., and Dubey, N. K. (2020b). Nanostructured Pimpinella anisum essential oil as novel green food preservative against fungal infestation, aflatoxin B1 contamination and deterioration of nutritional qualities. Food Chem. 344:128574. doi: $10.1016 /$ j.foodchem. 2020.128574

Das, S., Singh, V. K., Dwivedy, A. K., Chaudhari, A. K., and Dubey, N. K. (2021a). Eugenol loaded chitosan nanoemulsion for food protection and inhibition of Aflatoxin B1 synthesizing genes based on molecular docking. Carbohydr. Polymers 255:117339. doi: 10.1016/j.carbpol.2020.117339

Das, S., Singh, V. K., Dwivedy, A. K., Chaudhari, A. K., and Dubey, N. K. (2021b). Anethum graveolens essential oil encapsulation in chitosan nanomatrix: investigations on in vitro release behavior, organoleptic attributes, and efficacy as potential delivery vehicles against biodeterioration of rice (Oryza sativa L.). Food Bioprocess Technol. 14, 1-23. doi: 10.1007/s11947-02102589-z

Das, S., Singh, V. K., Dwivedy, A. K., Chaudhari, A. K., Upadhyay, N., Singh, A., et al. (2019a). Antimicrobial activity, antiaflatoxigenic potential and in situ efficacy of novel formulation comprising of Apium graveolens essential oil and its major component. Pestic. Biochem. Physiol. 160, 102-111. doi: 10.1016/j.pestbp.2019.07.013

Das, S., Singh, V. K., Dwivedy, A. K., Chaudhari, A. K., Upadhyay, N., Singh, P., et al. (2019b). Encapsulation in chitosan-based nanomatrix as an efficient green technology to boost the antimicrobial, antioxidant and in situ efficacy 
of Coriandrum sativum essential oil. Int. J. Biol. Macromol. 133, 294-305. doi: 10.1016/j.ijbiomac.2019.04.070

de Sá Silva, C., de Figueiredo, H. M., Stamford, T. L. M., and da Silva, L. H. M. (2019). Inhibition of Listeria monocytogenes by Melaleuca alternifolia (tea tree) essential oil in ground beef. Int. J. Food Microbiol. 293, 79-86. doi: 10.1016/j.ijfoodmicro.2019.01.004

Debonne, E., Van Bockstaele, F., De Leyn, I., Devlieghere, F., and Eeckhout, M. (2018). Validation of in-vitro antifungal activity of thyme essential oil on Aspergillus niger and Penicillium paneum through application in parbaked wheat and sourdough bread. LWT 87, 368-378. doi: 10.1016/j.lwt.2017. 09.007

Dègnon, R. G., Allagbé, A. C., Adjou, E. S., and Dahouenon-Ahoussi, E. (2019). Antifungal activities of Cymbopogon citratus essential oil against Aspergillus species isolated from fermented fish products of Southern Benin. J. Food Qual. Hazards Control. 6, 53-57. doi: 10.18502/jfqhc.6.2.955

Delshadi, R., Bahrami, A., Tafti, A. G., Barba, F. J., and Williams, L. L. (2020). Micro and nano-encapsulation of vegetable and essential oils to develop functional food products with improved nutritional profiles. Trends Food Sci. Technol. 104, 72-83. doi: 10.1016/j.tifs.2020.07.004

Dhif, W., Bellili, S., Jazi, S., Bahloul, N., and Mnif, W. (2016). Essential oils' chemical characterization and investigation of some biological activities: a critical review. Medicines 3:25. doi: 10.3390/medicines3040025

Diao, W. R., Hu, Q. P., Zhang, H., and Xu, J. G. (2014). Chemical composition, antibacterial activity and mechanism of action of essential oil from seeds of fennel (Foeniculum vulgare Mill.). Food Control 35, 109-116. doi: 10.1016/j.foodcont.2013.06.056

Dima, C., Cotârlet, M., Alexe, P., and Dima, S. (2014). Microencapsulation of essential oil of pimento [Pimenta dioica (L) Merr.] by chitosan/k-carrageenan complex coacervation method. Innov. Food Sci. Emerg. Technol. 22, 203-211. doi: $10.1016 /$ j.ifset.2013.12.020

Djenane, D. (2015). Chemical profile, antibacterial and antioxidant activity of Algerian citrus essential oils and their application in Sardina pilchardus. Foods 4, 208-228. doi: 10.3390/foods4020208

Djenane, D., Yangüela, J., Montañés, L., Djerbal, M., and Roncalés, P. (2011). Antimicrobial activity of Pistacia lentiscus and Satureja montana essential oils against Listeria monocytogenes CECT 935 using laboratory media: efficacy and synergistic potential in minced beef. Food Control 22, 1046-1053. doi: 10.1016/j.foodcont.2010.12.015

Djihane, B., Wafa, N., Elkhamssa, S., Maria, A. E., and Mihoub, Z. M. (2017). Chemical constituents of Helichrysum italicum (Roth) G. Don essential oil and their antimicrobial activity against Gram-positive and Gram-negative bacteria, filamentous fungi and Candida albicans. Saudi Pharma. J. 25, 780-787. doi: 10.1016/j.jsps.2016.11.001

Donsì, F., Annunziata, M., Sessa, M., and Ferrari, G. (2011). Nanoencapsulation of essential oils to enhance their antimicrobial activity in foods. LWT Food Sci. Technol. 44, 1908-1914. doi: 10.1016/j.lwt.2011.03.003

Donsì, F., and Ferrari, G. (2016). Essential oil nanoemulsions as antimicrobial agents in food. J. Biotechnol. 233, 106-120. doi: 10.1016/j.jbiotec.2016.07.005

Dorman, H. J. D., and Deans, S. G. (2000). Antimicrobial agents from plants: antibacterial activity of plant volatile oils. J. Appl. Microbiol. 88, 308-316. doi: 10.1046/j.1365-2672.2000.00969.x

Dwivedy, A. K., Kumar, M., Upadhyay, N., Prakash, B., and Dubey, N. K. (2016). Plant essential oils against food borne fungi and mycotoxins. Curr. Opin. Food Sci. 11, 16-21. doi: 10.1016/j.cofs.2016.08.010

Dwivedy, A. K., Prakash, B., Chanotiya, C. S., Bisht, D., and Dubey, N. K. (2017). Chemically characterized Mentha cardiaca L. essential oil as plant based preservative in view of efficacy against biodeteriorating fungi of dry fruits, aflatoxin secretion, lipid peroxidation and safety profile assessment. Food Chem. Toxicol. 106, 175-184. doi: 10.1016/j.fct.2017.05.043

Dwivedy, A. K., Singh, V. K., Prakash, B., and Dubey, N. K. (2018). Nanoencapsulated Illicium verum Hook.f. essential oil as an effective novel plant-based preservative against aflatoxin B1 production and free radical generation. Food Chem. Toxicol. 111, 102-113. doi: 10.1016/j.fct.2017. 11.007

Ehsani, A., Hashemi, M., Naghibi, S. S., Mohammadi, S., and Khalili Sadaghiani, S. (2016). Properties of Bunium persicum essential oil and its application in Iranian white cheese against Listeria monocytogenes and Escherichia coli O157: H7. J. Food Saf. 36, 563-570. doi: 10.1111/jfs.12277
El Khoury, R., Atoui, A., Verheecke, C., Maroun, R., El Khoury, A., and Mathieu, F. (2016). Essential oils modulate gene expression and ochratoxin A production in Aspergillus carbonarius. Toxins 8:242. doi: 10.3390/toxins 8080242

Ellse, L., and Wall, R. (2014). The use of essential oils in veterinary ectoparasite control: a review. Med. Vet. Entomol. 28, 233-243. doi: 10.1111/mve.12033

Elshafie, H. S., and Camele, I. (2016). "Chapter 5: Investigating the effects of plant essential oils on postharvest fruit decay," in Fungal Pathogenicity (Intechopen), 83-98. doi: 10.5772/62568

Esmaeili, H., Karami, A., and Maggi, F. (2018). Essential oil composition, total phenolic and flavonoids contents, and antioxidant activity of Oliveria decumbens Vent. (Apiaceae) at different phenological stages. J. Cleaner Prod. 198, 91-95. doi: 10.1016/j.jclepro.2018.07.029

Fall, R., Ngom, S., Sall, D., Sembène, M., and Samb, A. (2017). Chemical characterization of essential oil from the leaves of Callistemon viminalis (DR) and Melaleuca leucadendron (Linn.). Asian Pac. J. Trop. Biomed. 7, 347-351. doi: 10.1016/j.apjtb.2017.01.004

Falleh, H., Jemaa, M. B., Saada, M., and Ksouri, R. (2020). Essential oils: a promising eco-friendly food preservative. Food Chem. 330:127268. doi: 10.1016/j.foodchem.2020.127268

Fancello, F., Petretto, G. L., Zara, S., Sanna, M. L., Addis, R., and Maldini, M. (2016). Chemical characterization, antioxidant capacity and antimicrobial activity against food related microorganisms of Citrus limon var. pompia leaf essential oil. LWT Food Sci. Technol. 69, 579-585. doi: 10.1016/j.lwt.2016.02.018

Frazão, G. G. S., Blank, A. F., and de Aquino Santana, L. C. L. (2017). Optimisation of edible chitosan coatings formulations incorporating Myrcia ovata Cambessedes essential oil with antimicrobial potential against foodborne bacteria and natural microflora of mangaba fruits. LWT Food Sci. Technol. 79, 1-10. doi: 10.1016/j.lwt.2017.01.011

Geetha, V., and Chakravarthula, S. N. (2018). Chemical composition and antiinflammatory activity of Boswellia ovalifoliolata essential oils from leaf and bark. J. Forestry Res. 29, 373-381. doi: 10.1007/s11676-017-0457-9

Gehrke, I. T., Neto, A. T., Pedroso, M., Mostardeiro, C. P., Da Cruz, I. B., Silva, U. F., et al. (2013). Antimicrobial activity of Schinus lentiscifolius (Anacardiaceae). J. Ethnopharmacol. 148, 486-491. doi: 10.1016/j.jep.2013.04.043

Gharby, S., Asdadi, A., Ibourki, M., Hamdouch, A., Ainane, T., and Hassani, L. A. I. (2020). Chemical characterization of the essential oil from aerial parts of Lavandula rejdalii Upson \& Jury, a medicinal plant endemic to morocco. J. Essen. Oil Bear. Plants 23, 1422-1427. doi: 10.1080/0972060X.2020.1870575

Guerra, I. C. D., de Oliveira, P. D. L., Santos, M. M. F., Lúcio, A. S. S. C., Tavares, J. F., Barbosa-Filho, J. M., et al. (2016). The effects of composite coatings containing chitosan and Mentha (piperita L. or $x$ villosa Huds) essential oil on postharvest mold occurrence and quality of table grape cv. Isabella. Innov. Food Sci. Emerg. Technol. 34, 112-121. doi: 10.1016/j.ifset.2016.01.008

Gutiérrez-del-Río, I., Fernández, J., and Lombó, F. (2018). Plant nutraceuticals as antimicrobial agents in food preservation: terpenoids, polyphenols and thiols. Int. J. Antimicrob. Agents 52, 309-315. doi: 10.1016/j.ijantimicag.2018.04.024

Han, Y., Sun, Z., and Chen, W. (2020). Antimicrobial susceptibility and antibacterial mechanism of limonene against Listeria monocytogenes. Molecules 25:33. doi: $10.3390 /$ molecules 25010033

Harmankaya, S., and Vatansever, L. (2017). The effect of essential oils of rosemary and clove on shelf life chicken meat. Van Vet. J. 28, 11-19. Available online at: http://vfdergi.yyu.edu.tr/archive/201

Hasheminejad, N., Khodaiyan, F., and Safari, M. (2019). Improving the antifungal activity of clove essential oil encapsulated by chitosan nanoparticles. Food Chem. 275, 113-122. doi: 10.1016/j.foodchem.2018.09.085

Helander, I. M., Alakomi, H. L., Latva-Kala, K., Mattila-Sandholm, T., Pol, I., Smid, E. J., et al. (1998). Characterization of the action of selected essential oil components on Gram-negative bacteria. J. Agric. Food Chem. 46, 3590-3595. doi: $10.1021 / \mathrm{j} f 980154 \mathrm{~m}$

Hosseini, S. A., and Meimandipour, A. (2018). Feeding broilers with thyme essential oil loaded in chitosan nanoparticles: an efficient strategy for successful delivery. Brit. Poultry Sci. 59, 669-678. doi: 10.1080/00071668.2018.1521511

Hsouna, A. B., Trigui, M., Mansour, R. B., Jarraya, R. M., Damak, M., and Jaoua, S. (2011). Chemical composition, cytotoxicity effect and antimicrobial activity of Ceratonia siliqua essential oil with preservative effects against Listeria inoculated in minced beef meat. Int. J. Food Microbiol. 148, 66-72. doi: 10.1016/j.ijfoodmicro.2011.04.028 
Hu, W., Li, C., Dai, J., Cui, H., and Lin, L. (2019). Antibacterial activity and mechanism of Litsea cubeba essential oil against methicillinresistant Staphylococcus aureus (MRSA). Indus. Crops Prod. 130, 34-41. doi: 10.1016/j.indcrop.2018.12.078

Hu, Y., Zhang, J., Kong, W., Zhao, G., and Yang, M. (2017). Mechanisms of antifungal and anti-aflatoxigenic properties of essential oil derived from turmeric (Curcuma longa L.) on Aspergillus flavus. Food Chem. 220, 1-8. doi: 10.1016/j.foodchem.2016.09.179

Hu, Z., Yuan, K., Zhou, Q., Lu, C., Du, L., and Liu, F. (2021). Mechanism of antifungal activity of Perilla frutescens essential oil against Aspergillus flavus by transcriptomic analysis. Food Control 123:107703. doi: 10.1016/j.foodcont.2020.107703

Hui, X., Yan, G., Tian, F. L., Li, H., and Gao, W. Y. (2017). Antimicrobial mechanism of the major active essential oil compounds and their structure-activity relationship. Med. Chem. Res. 26, 442-449. doi: 10.1007/s00044-016-1762-0

Hyldgaard, M., Mygind, T., and Meyer, R. L. (2012). Essential oils in food preservation: mode of action, synergies, and interactions with food matrix components. Front. Microbiol. 3:12. doi: 10.3389/fmicb.2012.00012

Iseppi, R., Sabia, C., de Niederhäusern, S., Pellati, F., Benvenuti, S., Tardugno, R., et al. (2019). Antibacterial activity of Rosmarinus officinalis L. and Thymus vulgaris $\mathrm{L}$. essential oils and their combination against food-borne pathogens and spoilage bacteria in ready-to-eat vegetables. Nat. Prod. Res. 33, 3568-3572. doi: $10.1080 / 14786419.2018 .1482894$

Ishaq, A., Syed, Q. A., Ebner, P. D., and ur Rahman, H. U. (2021). Multiple hurdle technology to improve microbial safety, quality and oxidative stability of refrigerated raw beef. $L W T$ 138:110529. doi: 10.1016/j.lwt.2020.110529

Jamil, B., Abbasi, R., Abbasi, S., Imran, M., Khan, S. U., Ihsan, A., et al. (2016). Encapsulation of cardamom essential oil in chitosan nano-composites: in-vitro efficacy on antibiotic-resistant bacterial pathogens and cytotoxicity studies. Front. Microbiol. 7:1580. doi: 10.3389/fmicb.2016.01580

Jirovetz, L., Buchbauer, G., Stoyanova, A. S., Georgiev, E. V., and Damianova, S. T. (2003). Composition, quality control, and antimicrobial activity of the essential oil of long-time stored dill (Anethum graveolens L.) seeds from Bulgaria. J. Agric. Food Chem. 51, 3854-3857. doi: 10.1021/jf030004y

Josić, D., Rešetar, D., Peršurić, Ž., Martinović, T., and Pavelić, S. K. (2017). "Detection of microbial toxins by-omics methods: a growing role of proteomics," in Proteomics in Food Science, ed M. Colgrave (Brisbane, QLD: Academic Press), 485-506. doi: 10.1016/B978-0-12-804007-2.00029-1

Ju, J., Xie, Y., Yu, H., Guo, Y., Cheng, Y., Zhang, R., et al. (2020). Major components in Lilac and Litsea cubeba essential oils kill Penicillium roqueforti through mitochondrial apoptosis pathway. Indus. Crops Prod. 149:112349. doi: 10.1016/j.indcrop.2020.112349

Ju, J., Xu, X., Xie, Y., Guo, Y., Cheng, Y., Qian, H., et al. (2018). Inhibitory effects of cinnamon and clove essential oils on mold growth on baked foods. Food Chem. 240, 850-855. doi: 10.1016/j.foodchem.2017.07.120

Jummes, B., Sganzerla, W. G., da Rosa, C. G., Noronha, C. M., Nunes, M. R., Bertoldi, F. C., et al. (2020). Antioxidant and antimicrobial poly- $\varepsilon$-caprolactone nanoparticles loaded with Cymbopogon martinii essential oil. Biocatal. Agric. Biotechnol. 23:101499. doi: 10.1016/j.bcab.2020.101499

Kačániová, M., Galovičová, L., Ivanišová, E., Vukovic, N. L., Štefániková, J., Valková, V., et al. (2020). Antioxidant, antimicrobial and antibiofilm activity of coriander (Coriandrum sativum L.) essential oil for its application in foods. Foods 9:282. doi: 10.3390/foods9030282

Kalagatur, N. K., Nirmal Ghosh, O. S., Sundararaj, N., and Mudili, V. (2018). Antifungal activity of chitosan nanoparticles encapsulated with Cymbopogon martinii essential oil on plant pathogenic fungi Fusarium graminearum. Front. Pharmacol. 9:610. doi: 10.3389/fphar.2018.00610

Kiran, S., Kujur, A., and Prakash, B. (2016). Assessment of preservative potential of Cinnamomum zeylanicum Blume essential oil against food borne molds, aflatoxin B1 synthesis, its functional properties and mode of action. Innov. Food Sci. Emerg. Technol. 37, 184-191. doi: 10.1016/j.ifset.2016.08.018

Kirkpinar, F. I. G. E. N., Ünlü, H. B., Serdaroglu, M., and Turp, G. Y. (2014). Effects of dietary oregano and garlic essential oils on carcass characteristics, meat composition, colour, $\mathrm{pH}$ and sensory quality of broiler meat. Br. Poultry Sci. 55, 157-166. doi: 10.1080/00071668.2013.879980

Kollanoor-Johny, A., Mattson, T., Baskaran, S. A., Amalaradjou, M. A., Babapoor, S., March, B., et al. (2012). Reduction of Salmonella enterica serovar Enteritidis colonization in 20-day-old broiler chickens by the plant-derived compounds trans-cinnamaldehyde and eugenol. Appl. Environ. Microbiol. 78, 2981-2987. doi: 10.1128/AEM.07643-11

Kringel, D. H., da Silva, W. M. F., Biduski, B., Waller, S. B., Lim, L. T., Dias, A. R. G., et al. (2020). Free and encapsulated orange essential oil into a $\beta$-cyclodextrin inclusion complex and zein to delay fungal spoilage in cakes. J. Food Process. Preserv. 44:e14411. doi: 10.1111/jfpp.14411

Kumar, A., Singh, P. P., Gupta, V., and Prakash, B. (2020). Assessing the antifungal and aflatoxin $\mathrm{B} 1$ inhibitory efficacy of nanoencapsulated antifungal formulation based on combination of Ocimum spp. essential oils. Int. J. Food Microbiol. 330:108766. doi: 10.1016/j.ijfoodmicro.2020.108766

Kumar, M., Dwivedy, A. K., Sarma, P., Dkhar, M. S., Kayang, H., Raghuwanshi, R., et al. (2020). Chemically characterised Artemisia nilagirica (Clarke) Pamp. essential oil as a safe plant-based preservative and shelf-life enhancer of millets against fungal and aflatoxin contamination and lipid peroxidation. Plant Biosyst. 154, 269-276. doi: 10.1080/11263504.2019.1587539

Kumar, M., Sarma, P., Dkhar, M. S., Kayang, H., Raghuwanshi, R., and Dubey, N. K. (2018). Assessment of chemically characterised Gaultheria fragrantissima Wall. essential oil and its major component as safe plant based preservative for millets against fungal, aflatoxin contamination and lipid peroxidation during storage. J. Food Sci. Technol. 55, 111-119. doi: 10.1007/s13197-017-2842-y

Lappa, I. K., Simini, E., Nychas, G. J. E., and Panagou, E. Z. (2017). In vitro evaluation of essential oils against Aspergillus carbonarius isolates and their effects on Ochratoxin A related gene expression in synthetic grape medium. Food Control 73, 71-80. doi: 10.1016/j.foodcont.2016.08.016

Lasram, S., Zemni, H., Hamdi, Z., Chenenaoui, S., Houissa, H., Tounsi, M. S., et al. (2019). Antifungal and antiaflatoxinogenic activities of Carum carvi L., Coriandrum sativum L. seed essential oils and their major terpene component against Aspergillus flavus. Indus. Crops Prod. 134, 11-18. doi: 10.1016/j.indcrop.2019.03.037

Leimann, F. V., Gonçalves, O. H., Machado, R. A., and Bolzan, A. (2009). Antimicrobial activity of microencapsulated lemongrass essential oil and the effect of experimental parameters on microcapsules size and morphology. Mater. Sci. Eng. C 29, 430-436. doi: 10.1016/j.msec.2008.08.025

Li, B., Zhang, C., Peng, L., Liang, Z., Yan, X., Zhu, Y., et al. (2015). Comparison of essential oil composition and phenolic acid content of selected Salvia species measured by GC-MS and HPLC methods. Indus. Crops Products 69, 329-334. doi: 10.1016/j.indcrop.2015.02.047

Li, J., Ye, F., Lei, L., and Zhao, G. (2018). Combined effects of octenylsuccination and oregano essential oil on sweet potato starch films with an emphasis on water resistance. Int. J. Biol. Macromol. 115, 547-553. doi: 10.1016/j.ijbiomac.2018.04.093

Li, Y., Wang, Y., Kong, W., Yang, S., Luo, J., and Yang, M. (2020). Illicium verum essential oil, a potential natural fumigant in preservation of lotus seeds from fungal contamination. Food Chem. Toxicol. 141:111347. doi: 10.1016/j.fct.2020.111347

Liang, D., Xing, F., Selvaraj, J. N., Liu, X., Wang, L., Hua, H., et al. (2015). Inhibitory effect of cinnamaldehyde, citral, and eugenol on aflatoxin biosynthetic gene expression and aflatoxin B1 biosynthesis in Aspergillus flavus. J. Food Sci. 80, M2917-M2924. doi: 10.1111/1750-3841.13144

Liu, T., and Liu, L. (2020). Fabrication and characterization of chitosan nanoemulsions loading thymol or thyme essential oil for the preservation of refrigerated pork. Int. J. Biol. Macromol. 162, 1509-1515. doi: 10.1016/j.ijbiomac.2020.07.207

Liu, Y., Wang, S., Zhang, R., Lan, W., and Qin, W. (2017). Development of poly (lactic acid)/chitosan fibers loaded with essential oil for antimicrobial applications. Nanomaterials 7:194. doi: 10.3390/nano7070194

Locali-Pereira, A. R., Lopes, N. A., Menis-Henrique, M. E. C., Janzantti, N. S., and Nicoletti, V. R. (2020). Modulation of volatile release and antimicrobial properties of pink pepper essential oil by microencapsulation in singleand double-layer structured matrices. Int. J. Food Microbiol. 335:108890. doi: 10.1016/j.ijfoodmicro.2020.108890

Luciardi, M. C., Blázquez, M. A., Cartagena, E., Bardón, A., and Arena, M. E. (2016). Mandarin essential oils inhibit quorum sensing and virulence factors of Pseudomonas aeruginosa. LWT 68, 373-380. doi: 10.1016/j.lwt.2015. 12.056

Luo, W., Du, Z., Zheng, Y., Liang, X., Huang, G., and Zhang, Q. (2019). Phytochemical composition and bioactivities of essential 
oils from six Lamiaceae species. Indus. Crops Prod. 133, 357-364. doi: 10.1016/j.indcrop.2019.03.025

Mamadalieva, N. Z., Abdullaeva, N. S., Rosenau, T., Fakhrutdinova, M., Azimova, S. S., and Böhmdorfer, S. (2018). Composition of essential oils from four Apiaceae and Asteraceae species growing in Uzbekistan. Nat. Prod. Res. 32, 1118-1122. doi: 10.1080/14786419.2017.1375928

Mancini, E., Camele, I., Elshafie, H. S., De Martino, L., Pellegrino, C., Grulova, D., et al. (2014). Chemical composition and biological activity of the essential oil of Origanum vulgare ssp. hirtum from different areas in the Southern Apennines (Italy). Chem. Biodiver. 11, 639-651. doi: 10.1002/cbdv.201300326

Mani López, E., Valle Vargas, G. P., Palou, E., and López Malo, A. (2018). Penicillium expansum inhibition on bread by lemongrass essential oil in vapor phase. J. Food Protect. 81, 467-471. doi: 10.4315/0362-028X.JFP-17-315

Matasyoh, J. C., Maiyo, Z. C., Ngure, R. M., and Chepkorir, R. (2009). Chemical composition and antimicrobial activity of the essential oil of Coriandrum sativum. Food Chem. 113, 526-529. doi: 10.1016/j.foodchem.2008. 07.097

Micciche, A., Rothrock Jr, M. J., Yang, Y., and Ricke, S. C. (2019). Essential oils as an intervention strategy to reduce Campylobacter in poultry production: a review. Front. Microbiol. 10:1058. doi: 10.3389/fmicb.2019.01058

Moosavy, M. H., Esmaeili, S., and Mostafavi, E. (2013). Antibacterial effect of Mentha spicata essential oil on Listeria monocytogenes in traditional lighvan cheese. J. Food Saf. 33, 509-514. doi: 10.1111/jfs.12083

Mothana, R. A., Khaled, J. M., Noman, O. M., Kumar, A., Alajmi, M. F., and Al-Rehaily (2018). Phytochemical analysis and evaluation of the cytotoxic, antimicrobial and antioxidant activities of essential oils from three Plectranthus species grown in Saudi Arabia. BMC Compl. Altern. Med. 18, 1-10. doi: 10.1186/s12906-018-2302-x

Mousavian, M., Bazgir, E., and Moradpour, A. (2018). Cinnamon bark essential oil compounds and its antifungal effects against fungal rotting of fruits. J. Crops Improv. 19, 907-920. doi: 10.22059/JCI.2017.60474

Moutaouafiq, S., Farah, A., Ez zoubi, Y., Ghanmi, M., Satrani, B., and Bousta, D. (2019). Antifungal activity of Pelargonium graveolens essential oil and its fractions against wood decay fungi. J. Essen. Oil Bear. Plants 22, 1104-1114. doi: 10.1080/0972060X.2019.1646164

Munhuweyi, K., Caleb, O. J., Lennox, C. L., van Reenen, A. J., and Opara, U. L. (2017). In vitro and in vivo antifungal activity of chitosan-essential oils against pomegranate fruit pathogens. Postharvest Biol. Technol. 129, 9-22. doi: 10.1016/j.postharvbio.2017.03.002

Narasimhan, B., and Dhake, A. S. (2006). Antibacterial principles from Myristica fragrans seeds. J. Med. Food 9, 395-399. doi: 10.1089/jmf.2006.9.395

Nerilo, S. B., Romoli, J. C. Z., Nakasugi, L. P., Zampieri, N. S., Mossini, S. A. G., Rocha, G. H. O., et al. (2020). Antifungal activity and inhibition of aflatoxins production by Zingiber officinale Roscoe essential oil against Aspergillus flavus in stored maize grains. Ciência Rural 50, 1-10. doi: 10.1590/0103-8478cr20190779

Nikkhah, M., and Hashemi, M. (2020). Boosting antifungal effect of essential oils using combination approach as an efficient strategy to control postharvest spoilage and preserving the jujube fruit quality. Postharvest Biol. Technol. 164:111159. doi: 10.1016/j.postharvbio.2020.111159

Nikmaram, N., Budaraju, S., Barba, F. J., Lorenzo, J. M., and Cox, R. B., Mallikarjunan, et al. (2018). Application of plant extracts to improve the shelflife, nutritional and health-related properties of ready-to-eat meat products. Meat Sci. 145, 245-255. doi: 10.1016/j.meatsci.2018.06.031

Nogueira, J. H., Gonçalez, E., Galleti, S. R., Facanali, R., Marques, M. O., and Felício, J. D. (2010). Ageratum conyzoides essential oil as aflatoxin suppressor of Aspergillus flavus. Int. J. Food Microbiol. 137, 55-60. doi: 10.1016/j.ijfoodmicro.2009.10.017

Noori, S., Zeynali, F., and Almasi, H. (2018). Antimicrobial and antioxidant efficiency of nanoemulsion-based edible coating containing ginger (Zingiber officinale) essential oil and its effect on safety and quality attributes of chicken breast fillets. Food Control 84, 312-320. doi: 10.1016/j.foodcont.2017.08.015

Nuzhat, T., and Vidyasagar, G. M. (2014). Antifungal investigations on plant essential oils. A review. Int. J. Pharm. 5 (Suppl. 2): 2013.

Oh, Y. A., Oh, Y. J., Song, A. Y., Won, J. S., Song, K. B., and Min, S. C. (2017). Comparison of effectiveness of edible coatings using emulsions containing lemongrass oil of different size droplets on grape berry safety and preservation. LWT 75, 742-750. doi: 10.1016/j.lwt.2016.10.033
Oliveira, R. C., Carvajal-Moreno, M., Correa, B., and Rojo-Callejas, F. (2020a). Cellular, physiological and molecular approaches to investigate the antifungal and anti-aflatoxigenic effects of thyme essential oil on Aspergillus flavus. Food Chem. 315:126096. doi: 10.1016/j.foodchem.2019.126096

Oliveira, R. C., Carvajal-Moreno, M., Mercado-Ruaro, P., Rojo-Callejas, F., and Correa, B. (2020b). Essential oils trigger an antifungal and anti-aflatoxigenic effect on Aspergillus flavus via the induction of apoptosis-like cell death and gene regulation. Food Control 110:107038. doi: 10.1016/j.foodcont.2019.107038

Omidbeygi, M., Barzegar, M., Hamidi, Z., and Naghdibadi, H. (2007). Antifungal activity of thyme, summer savory and clove essential oils against Aspergillus flavus in liquid medium and tomato paste. Food control 18, 1518-1523. doi: 10.1016/j.foodcont.2006.12.003

Ortega Ramirez, L. A., Silva Espinoza, B. A., Vargas Arispuro, I., Gonzalez Aguilar, G. A., Cruz Valenzuela, M. R., Nazzaro, F., et al. (2017). Combination of Cymbopogon citratus and Allium cepa essential oils increased antibacterial activity in leafy vegetables. J. Sci. Food Agric. 97, 2166-2173. doi: $10.1002 /$ jsfa. 8025

Ouedrhiri, W., Mounyr, B., Harki, E. H., Moja, S., and Greche, H. (2017). Synergistic antimicrobial activity of two binary combinations of marjoram, lavender, and wild thyme essential oils. Int. J. Food Properties 20, 3149-3158. doi: 10.1080/10942912.2017.1280504

Pavela, R., and Benelli, G. (2016). Essential oils as ecofriendly biopesticides? Challenges and constraints. Trends Plant Sci. 21, 1000-1007. doi: 10.1016/j.tplants.2016.10.005

Perczak, A., Gwiazdowska, D., Marchwińska, K., Juś, K., Gwiazdowski, R., and Waśkiewicz, A. (2019). Antifungal activity of selected essential oils against Fusarium culmorum and F. graminearum and their secondary metabolites in wheat seeds. Arch. Microbiol. 201, 1085-1097. doi: 10.1007/s00203-019-01673-5

Pereira, F. D. O., Mendes, J. M., Lima, I. O., Mota, K. S. D. L., Oliveira, W. A. D., and Lima, E. D. O. (2015). Antifungal activity of geraniol and citronellol, two monoterpenes alcohols, against Trichophyton rubrum involves inhibition of ergosterol biosynthesis. Pharm. Biol. 53, 228-234. doi: 10.3109/13880209.2014.913299

Pisoschi, A. M., Pop, A., Georgescu, C., Turcuş, V., Olah, N. K., and Mathe, E. (2018). An overview of natural antimicrobials role in food. Eur. J. Med. Chem 143, 922-935. doi: 10.1016/j.ejmech.2017.11.095

Pizzolitto, R. P., Jacquat, A. G., Usseglio, V. L., Achimón, F., Cuello, A. E., Zygadlo, J. A., et al. (2020). Quantitative-structure-activity relationship study to predict the antifungal activity of essential oils against Fusarium verticillioides. Food Control 108:106836. doi: 10.1016/j.foodcont.2019.106836

Prakash, B., Shukla, R., Singh, P., Mishra, P. K., Dubey, N. K., and Kharwar, R. N. (2011). Efficacy of chemically characterized Ocimum gratissimum L. essential oil as an antioxidant and a safe plant based antimicrobial against fungal and aflatoxin B1 contamination of spices. Food Res. Int. 44, 385-390. doi: 10.1016/j.foodres.2010.10.002

Qiu, C., Chang, R., Yang, J., Ge, S., Xiong, L., Zhao, M., et al. (2017). Preparation and characterization of essential oil-loaded starch nanoparticles formed by short glucan chains. Food Chem. 221, 1426-1433. doi: 10.1016/j.foodchem.2016.11.009

Radünz, M., da Trindade, M. L. M., Camargo, T. M., Radünz, A. L., Borges, C. D., Gandra, E. A., et al. (2019). Antimicrobial and antioxidant activity of unencapsulated and encapsulated clove (Syzygium aromaticum, L.) essential oil. Food Chem. 276, 180-186. doi: 10.1016/j.foodchem.2018.09.173

Radünz, M., dos Santos Hackbart, H. C., Camargo, T. M., Nunes, C. F. P., de Barros, F. A. P., Dal Magro, J., et al. (2020). Antimicrobial potential of spray drying encapsulated thyme (Thymus vulgaris) essential oil on the conservation of hamburger-like meat products. Int. J. Food Microbiol. 330:108696. doi: 10.1016/j.ijfoodmicro.2020.108696

Rai, M., Paralikar, P., Jogee, P., Agarkar, G., Ingle, A. P., Derita, M., et al. (2017). Synergistic antimicrobial potential of essential oils in combination with nanoparticles: emerging trends and future perspectives. Int. J. Pharm. 519, 67-78. doi: 10.1016/j.ijpharm.2017.01.013

Rajkovic, A. (2014). Microbial toxins and low level of foodborne exposure. Trends Food Sci. Technol. 38, 149-157. doi: 10.1016/j.tifs.2014. 04.006

Rajkovic, A., Jovanovic, J., Monteiro, S., Decleer, M., Andjelkovic, M., Foubert, A., et al. (2020). Detection of toxins involved in foodborne diseases caused by 
Gram-positive bacteria. Comprehen. Rev. Food Sci. Food Saf. 19, 1605-1657. doi: 10.1111/1541-4337.12571

Rakmai, J., Cheirsilp, B., Mejuto, J. C., Torrado-Agrasar, A., and Simal-Gándara, J. (2017). Physico-chemical characterization and evaluation of bio-efficacies of black pepper essential oil encapsulated in hydroxypropyl-beta-cyclodextrin. Food Hydrocolloids 65, 157-164. doi: 10.1016/j.foodhyd.2016.11.014

Rasooli, I., and Mirmostafa, S. A. (2003). Bacterial susceptibility to and chemical composition of essential oils from Thymus kotschyanus and Thymus persicus. J. Agric. Food Chem. 51, 2200-2205. doi: 10.1021/jf0261755

Rather, M. A., Dar, B. A., Sofi, S. N., Bhat, B. A., and Qurishi, M. A. (2016). Foeniculum vulgare: a comprehensive review of its traditional use, phytochemistry, pharmacology, and safety. Arab. J. Chem. 9, S1574-S1583. doi: 10.1016/j.arabjc.2012.04.011

Reddy, K. R. N., Salleh, B., Saad, B., Abbas, H. K., Abel, C. A., and Shier, W. T. (2010). An overview of mycotoxin contamination in foods and its implications for human health. Toxin Rev. 29, 3-26. doi: 10.3109/15569541003598553

Rehman, J. U., Ali, A., and Khan, I. A. (2014). Plant based products: use and development as repellents against mosquitoes: a review. Fitoterapia 95, 65-74. doi: 10.1016/j.fitote.2014.03.002

Rešetar, D., Pavelić, S. K., and Josić, D. (2015). Foodomics for investigations of food toxins. Curr. Opin. Food Sci. 4, 86-91. doi: 10.1016/j.cofs.2015.05.004

Restuccia, C., Conti, G. O., Zuccarello, P., Parafati, L., Cristaldi, A., and Ferrante, M. (2019). Efficacy of different citrus essential oils to inhibit the growth and B1 aflatoxin biosynthesis of Aspergillus flavus. Environ. Sci. Pollut. Res. 26, 31263-31272. doi: 10.1007/s11356-019-06169-9

Reyes-Jurado, F., Navarro-Cruz, A. R., Ochoa-Velasco, C. E., Palou, E., LópezMalo, A., and Ávila-Sosa, R. (2020). Essential oils in vapor phase as alternative antimicrobials: a review. Crit. Rev. Food Sci. Nutr. 60, 1641-1650. doi: 10.1080/10408398.2019.1586641

Ribes, S., Fuentes, A., and Barat, J. M. (2019). Effect of oregano (Origanum vulgare L. ssp. hirtum) and clove (Eugenia spp.) nanoemulsions on Zygosaccharomyces bailii survival in salad dressings. Food Chem. 295, 630-636. doi: $10.1016 /$ j.foodchem.2019.05.173

Ribes, S., Fuentes, A., Talens, P., Barat, J. M., Ferrari, G., and Donsì, F. (2017). Influence of emulsifier type on the antifungal activity of cinnamon leaf, lemon and bergamot oil nanoemulsions against Aspergillus niger. Food Control 73, 784-795. doi: 10.1016/j.foodcont.2016.09.044

Rojas-Graü, M. A., Raybaudi-Massilia, R. M., Soliva-Fortuny, R. C., AvenaBustillos, R. J., McHugh, T. H., and Martín-Belloso, O. (2007). Apple puree-alginate edible coating as carrier of antimicrobial agents to prolong shelf-life of fresh-cut apples. Postharvest Biol. Technol. 45, 254-264. doi: 10.1016/j.postharvbio.2007.01.017

Rudramurthy, G. R., Swamy, M. K., Sinniah, U. R., and Ghasemzadeh, A. (2016). Nanoparticles: alternatives against drug-resistant pathogenic microbes. Molecules 21:836. doi: 10.3390/molecules21070836

Saad, N. Y., Muller, C. D., and Lobstein, A. (2013). Major bioactivities and mechanism of action of essential oils and their components. Flavour Fragr. J. 28, 269-279. doi: 10.1002/ffj.3165

Sadeghi, E., Mohammadi, A., Jamilpanah, M., Bashiri, M., and Bohlouli, S. (2016). Antimicrobial effects of Mentha pulegium essential oil on Listeria monocytogenes in Iranian white cheese. J. Food Qual. Hazards Control 3, 20-24. Available online at: http://jfqhc.ssu.ac.ir/article-1-226-en.html

Sampaio, B. L., Edrada-Ebel, R., and Da Costa, F. B. (2016). Effect of the environment on the secondary metabolic profile of Tithonia diversifolia: a model for environmental metabolomics of plants. Sci. Rep. 6:29265. doi: $10.1038 /$ srep 29265

Sánchez-González, L., Pastor, C., Vargas, M., Chiralt, A., González-Martínez, C., and Cháfer, M. (2011). Effect of hydroxypropylmethylcellulose and chitosan coatings with and without bergamot essential oil on quality and safety of cold-stored grapes. Postharvest Biol. Technol. 60, 57-63. doi: 10.1016/j.postharvbio.2010.11.004

Saxena, P., Joshi, Y., Rawat, K., and Bisht, R. (2019). Biofilms: architecture, resistance, quorum sensing and control mechanisms. Indian J. Microbiol. 59, 3-12. doi: 10.1007/s12088-018-0757-6

Semeniuc, C. A., Pop, C. R., and Rotar, A. M. (2017). Antibacterial activity and interactions of plant essential oil combinations against Grampositive and Gram-negative bacteria. J. Food Drug Anal. 25, 403-408. doi: 10.1016/j.jfda.2016.06.002
Serrano, M., Martinez-Romero, D., Castillo, S., Guillén, F., and Valero, D. (2005). The use of natural antifungal compounds improves the beneficial effect of MAP in sweet cherry storage. Innov. Food Sci. Emerg. Technol. 6, 115-123. doi: 10.1016/j.ifset.2004.09.001

Shishir, M. R. I., Xie, L., Sun, C., Zheng, X., and Chen, W. (2018). Advances in micro and nano-encapsulation of bioactive compounds using biopolymer and lipid-based transporters. Trends Food Sci. Technol. 78, 34-60. doi: 10.1016/j.tifs.2018.05.018

Shukla, R., Singh, P., Prakash, B., and Dubey, N. K. (2012). Antifungal, aflatoxin inhibition and antioxidant activity of Callistemon lanceolatus (Sm.) Sweet essential oil and its major component 1, 8-cineole against fungal isolates from chickpea seeds. Food Control 25, 27-33. doi: 10.1016/j.foodcont.2011.10.010

Silvestre, W. P., Livinalli, N. F., Baldasso, C., and Tessaro, I. C. (2019). Pervaporation in the separation of essential oil components: a review. Trends Food Sci. Technol. 93, 42-52. doi: 10.1016/j.tifs.2019.09.003

Singh, A., Chaudhari, A. K., Das, S., Singh, V. K., Dwivedy, A. K., Shivalingam, R. K., et al. (2020a). Assessment of preservative potential of Bunium persicum (Boiss) essential oil against fungal and aflatoxin contamination of stored masticatories and improvement in efficacy through encapsulation into chitosan nanomatrix. Environ. Sci. Pollut. Res. 27, 27635-27650. doi: 10.1007/s11356-020-08872-4

Singh, A., Deepika, A., Chaudhari, A. K., Das, S., Prasad, J., Dwivedy, A. K., et al.and Dubey, N. K. (2020b). Efficacy of Cinnamomum cassia essential oil against food-borne molds and aflatoxin $\mathrm{B}_{1}$ contamination. Plant Biosyst. 1-9. doi: 10.1080/11263504.2020.1810804

Smith, R. L., Cohen, S. M., Doull, J., Feron, V. J., Goodman, J. I., Marnett, L. J., et al. (2005). A procedure for the safety evaluation of natural flavor complexes used as ingredients in food: essential oils. Food Chem. Toxicol. 43, 345-363. doi: 10.1016/j.fct.2004.11.007

Snoussi, M., Noumi, E., Punchappady-Devasya, R., Trabelsi, N., Kanekar, S., Nazzaro, F., et al. (2018). Antioxidant properties and anti-quorum sensing potential of Carum copticum essential oil and phenolics against Chromobacterium violaceum. J. Food Sci. Technol. 55, 2824-2832. doi: 10.1007/s13197-018-3219-6

Sokolik, C. G., Ben-Shabat-Binyamini, R., Gedanken, A., and Lellouche, J. P. (2018). Proteinaceous microspheres as a delivery system for carvacrol and thymol in antibacterial applications. Ultrasonics Sonochem. 41, 288-296. doi: 10.1016/j.ultsonch.2017.09.032

Soković, M., Glamočlija, J., Marin, P. D., Brkić, D., and Van Griensven, L. J. (2010). Antibacterial effects of the essential oils of commonly consumed medicinal herbs using an in vitro model. Molecules 15, 7532-7546. doi: 10.3390/molecules 15117532

Songsamoe, S., Matan, N., and Matan, N. (2017). Antifungal activity of Michelia alba oil in the vapor phase and the synergistic effect of major essential oil components against Aspergillus flavus on brown rice. Food Control 77, 150-157. doi: 10.1016/j.foodcont.2017.02.010

Sotelo-Boyás, M., Correa-Pacheco, Z., Bautista-Baños, S., and y Gómez, Y. G. (2017). Release study and inhibitory activity of thyme essential oil-loaded chitosan nanoparticles and nanocapsules against foodborne bacteria. Int. J. Biol. Macromol. 103, 409-414. doi: 10.1016/j.ijbiomac.2017.05.063

Sun, X., Cameron, R. G., and Bai, J. (2020). Effect of spray-drying temperature on physicochemical, antioxidant and antimicrobial properties of pectin/sodium alginate microencapsulated carvacrol. Food Hydrocolloids 100:105420. doi: 10.1016/j.foodhyd.2019.105420

Swamy, M. K., Akhtar, M. S., and Sinniah, U. R. (2016). Antimicrobial properties of plant essential oils against human pathogens and their mode of action: an updated review. Evid. Based Compl. Altern. Med. 2016:3012462. doi: $10.1155 / 2016 / 3012462$

Talón, E., Lampi, A. M., Vargas, M., Chiralt, A., Jouppila, K., and GonzálezMartínez, C. (2019). Encapsulation of eugenol by spray-drying using whey protein isolate or lecithin: release kinetics, antioxidant and antimicrobial properties. Food Chem. 295, 588-598. doi: 10.1016/j.foodchem.2019. 05.115

Tehrani, F., and Sadeghi, E. (2015). Effect of mint essential oil on growth of Listeria monocytogenes during the ripening and storage of iranian white brined cheese. J. Appl. Environ. Biol. Sci. 5, 150-154.

Teodoro, R. A. R., de Barros Fernandes, R. V., Botrel, D. A., Borges, S. V., and de Souza, A. U. (2014). Characterization of microencapsulated rosemary essential 
oil and its antimicrobial effect on fresh dough. Food Bioprocess Technol. 7, 2560-2569. doi: 10.1007/s11947-014-1302-1

Tian, J., Ban, X., Zeng, H., He, J., Chen, Y., and Wang, Y. (2012). The mechanism of antifungal action of essential oil from dill (Anethum graveolens L.) on Aspergillus flavus. PLoS ONE 7:e30147. doi: 10.1371/journal.pone.0030147

Tian, W. L., Lei, L. L., Zhang, Q., and Li, Y. (2016). Physical stability and antimicrobial activity of encapsulated cinnamaldehyde by self-emulsifying nanoemulsion. J. Food Process Eng. 39, 462-471. doi: 10.1111/jfpe.12237

Tongnuanchan, P., and Benjakul, S. (2014). Essential oils: extraction, bioactivities, and their uses for food preservation. J. Food Sci. 79, R1231-R1249. doi: 10.1111/1750-3841.12492

Trombetta, D., Castelli, F., Sarpietro, M. G., Venuti, V., Cristani, M., Daniele, C., et al. (2005). Mechanisms of antibacterial action of three monoterpenes. Antimicrobial Agents Chemother. 49, 2474-2478. doi: 10.1128/AAC.49.6.2474-2478.2005

Upadhyay, N., Singh, V. K., Dwivedy, A. K., Das, S., Chaudhari, A. K., and Dubey, N. K. (2018). Cistus ladanifer L. essential oil as a plant based preservative against molds infesting oil seeds, aflatoxin $\mathrm{B}_{1}$ secretion, oxidative deterioration and methylglyoxal biosynthesis. LWT 92, 395-403. doi: 10.1016/j.lwt.2018.02.040

Upadhyaya, I., Upadhyay, A., Kollanoor-Johny, A., Mooyottu, S., Baskaran, S. A., Yin, H. B., et al. (2015). In-feed supplementation of transcinnamaldehyde reduces layer-chicken egg-borne transmission of Salmonella enterica serovar enteritidis. Appl. Environ. Microbiol. 81, 2985-2994. doi: 10.1128/AEM.03809-14

Varona, S., Rojo, S. R., Martín, Á., Cocero, M. J., Serra, A. T., Crespo, T., et al. (2013). Antimicrobial activity of lavandin essential oil formulations against three pathogenic food-borne bacteria. Indus. Crops Products 42, 243-250. doi: 10.1016/j.indcrop.2012.05.020

Vasconcelos, N. G., Croda, J., and Simionatto, S. (2018). Antibacterial mechanisms of cinnamon and its constituents: a review. Microb. Pathog. 120, 198-203. doi: 10.1016/j.micpath.2018.04.036

Vazirian, M., Kashani, S. T., Ardekani, M. R. S., Khanavi, M., Jamalifar, H., Fazeli, M. R., et al. (2012). Antimicrobial activity of lemongrass (Cymbopogon citratus (DC) Stapf.) essential oil against food-borne pathogens added to cream-filled cakes and pastries. J. Essen. Oil Res. 24, 579-582. doi: 10.1080/10412905.2012.729920

Villa-Ruano, N., Pacheco-Hernández, Y., Rubio-Rosas, E., Lozoya-Gloria, E., Mosso-González, C., Ramón-Canul, L. G., et al. (2015). Essential oil composition and biological/pharmacological properties of Salmea scandens (L.) DC. Food Control 57, 177-184. doi: 10.1016/j.foodcont.2015.04.018

Vinciguerra, V., Rojas, F., Tedesco, V., Giusiano, G., and Angiolella, L. (2019). Chemical characterization and antifungal activity of Origanum vulgare, Thymus vulgaris essential oils and carvacrol against Malassezia furfur. Nat. Prod. Res. 33, 3273-3277. doi: 10.1080/14786419.2018.1468325

Voda, K., Boh, B., and Vrtačnik, M. (2004). A quantitative structure-antifungal activity relationship study of oxygenated aromatic essential oil compounds using data structuring and PLS regression analysis. J. Mol. Model. 10, 76-84. doi: 10.1007/s00894-003-0174-5

Wagle, B. R., Upadhyay, A., Arsi, K., Shrestha, S., Venkitanarayanan, K., Donoghue, A. M., et al. (2017). Application of $\beta$-resorcylic acid as potential antimicrobial feed additive to reduce Campylobacter colonization in broiler chickens. Front. Microbiol. 8:599. doi: 10.3389/fmicb.2017.00599

Wang, L., Jin, J., Liu, X., Wang, Y., Liu, Y., Zhao, Y., et al. (2018). Effect of cinnamaldehyde on morphological alterations of Aspergillus ochraceus and expression of key genes involved in ochratoxin A biosynthesis. Toxins 10:340. doi: $10.3390 /$ toxins 10090340

Wang, R., Wang, R., and Yang, B. (2009). Extraction of essential oils from five cinnamon leaves and identification of their volatile compound compositions. Innov. Food Sci. Emerg. Technol. 10, 289-292. doi: 10.1016/j.ifset.2008.12.002
Wang, Y., Yin, C., Cheng, X., Li, G., Yang, S., and Zhu, X. (2020). $\beta$ Cyclodextrin inclusion complex containing Litsea cubeba essential oil: preparation, optimization, physicochemical, and antifungal characterization. Coatings 10:850. doi: 10.3390/coatings10090850

Wen, P., Zhu, D. H., Feng, K., Liu, F. J., Lou, W. Y., Li, N., et al. (2016). Fabrication of electrospun polylactic acid nanofilm incorporating cinnamon essential oil/ $\beta$ cyclodextrin inclusion complex for antimicrobial packaging. Food Chem. 196, 996-1004. doi: 10.1016/j.foodchem.2015.10.043

Wińska, K., Maczka, W., Łyczko, J., Grabarczyk, M., Czubaszek, A., and Szumny, A. (2019). Essential oils as antimicrobial agents-myth or real alternative?. Molecules 24:2130. doi: 10.3390/molecules24112130

Yang, K., Liu, A., Hu, A., Li, J., Zen, Z., Liu, Y., et al. (2020). Preparation and characterization of cinnamon essential oil nanocapsules and comparison of volatile components and antibacterial ability of cinnamon essential oil before and after encapsulation. Food Control 123:107783. doi: 10.1016/j.foodcont.2020.107783

Yassein, A. S., El-Said, A. H., and El-Dawy, E. G. (2020). Biocontrol of toxigenic Aspergillus strains isolated from baby foods by essential oils. Flavour Fragr. J. 35, 182-189. doi: 10.1002/ffj.3551

Zhang, H., Liang, Y., Li, X., and Kang, H. (2020). Effect of chitosan-gelatin coating containing nano-encapsulated tarragon essential oil on the preservation of pork slices. Meat Sci. 166:108137. doi: 10.1016/j.meatsci.2020.108137

Zhang, L. L., Zhang, L. F., Hu, Q. P., Hao, D. L., and Xu, J. G. (2017). Chemical composition, antibacterial activity of Cyperus rotundus rhizomes essential oil against Staphylococcus aureus via membrane disruption and apoptosis pathway. Food Control 80, 290-296. doi: 10.1016/j.foodcont.2017.05.016

Zhang, Y., Liu, X., Wang, Y., Jiang, P., and Quek, S. (2016). Antibacterial activity and mechanism of cinnamon essential oil against Escherichia coli and Staphylococcus aureus. Food Control 59, 282-289. doi: 10.1016/j.foodcont.2015.05.032

Zhaveh, S., Mohsenifar, A., Beiki, M., Khalili, S. T., Abdollahi, A., RahmaniCherati, T., et al. (2015). Encapsulation of Cuminum cyminum essential oils in chitosan-caffeic acid nanogel with enhanced antimicrobial activity against Aspergillus flavus. Indus. Crops Prod. 69, 251-256. doi: 10.1016/j.indcrop.2015.02.028

Zhou, T., Wang, X., Ye, B., Shi, L., Bai, X., and Lai, T. (2018). Effects of essential oil decanal on growth and transcriptome of the postharvest fungal pathogen Penicillium expansum. Postharvest Biol. Technol. 145, 203-212. doi: 10.1016/j.postharvbio.2018.07.015

Zinoviadou, K. G., Koutsoumanis, K. P., and Biliaderis, C. G. (2009). Physico-chemical properties of whey protein isolatefilms containing oregano oil and their antimicrobial action against spoilageflora of fresh beef.Meat Science 82, 338-345. doi: 10.1016/j.meatsci.2009. 02.004

Conflict of Interest: The authors declare that the research was conducted in the absence of any commercial or financial relationships that could be construed as a potential conflict of interest.

The reviewer, ND, declared a shared affiliation, though no collaboration, with the authors to the handling Editor.

Copyright () 2021 Maurya, Prasad, Das and Dwivedy. This is an open-access article distributed under the terms of the Creative Commons Attribution License (CC BY). The use, distribution or reproduction in other forums is permitted, provided the original author(s) and the copyright owner(s) are credited and that the original publication in this journal is cited, in accordance with accepted academic practice. No use, distribution or reproduction is permitted which does not comply with these terms. 